\title{
ENFORCEMENT REMEDIES OF CREDITORS
}

\section{RODERICK J. WOOD*}

This article begins by discussing the history of the enforcement remedies possessed by creditors against debtor's goods in Alberta. The author examines the new Personal Property Security Act legislation and the more recent Civil Enforcement Act He outlines the objectives of such legislation and the competing policy concerns that need to be considered when such legislation is drafted. The article concludes by assessing the approach taken in relation to the four rudimentary elements of an enforcement system: seizure, sale, restrictions of enforcement, and judicial intervention.
L'auteur aborde en premier lieu l'histoire des recours dont disposent les créanciers à l'endroit des biens du débiteur en Alberta. Il examine le nouvel Personal Property Security Act et le plus récent Civil Enforcement Act. Il délimite aussi les objectifs de ces lois et les problèmes de politiques concurrentes à prendre en compte à l'étape de la rédaction législative. II conclut en évaluant l'approche adoptée par rapport aux quatre éléments rudimentaires d'un régime de mise en application de la Loi : saisie, vente, limites d'exécution et intervention judiciaire.

\section{TABLE OF CONTENTS}

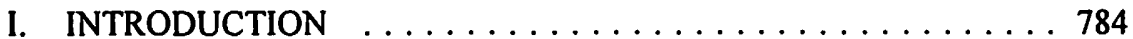

II. ORIGINS OF THE OLDER SYSTEM $\ldots \ldots \ldots \ldots \ldots \ldots \ldots 785$

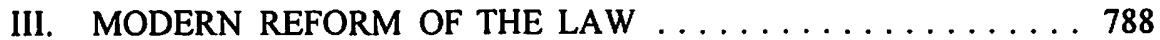

.A. THE REFORM OF PERSONAL

PROPERTY SECURITY LAW . . . . . . . . . . . . 789

B. THE REFORM OF JUDGMENT

ENFORCEMENT LAW .................. 790

C. AMENDMENT OF THE

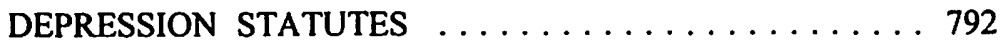

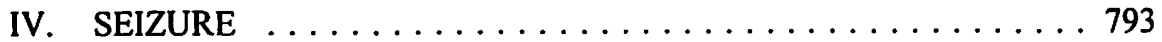

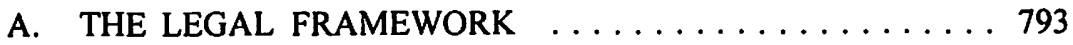

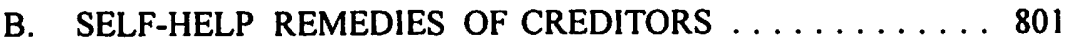

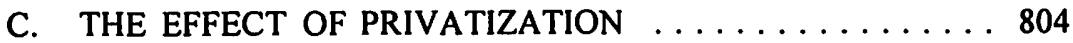

V. SALE OR OTHER DISPOSITION $\ldots \ldots \ldots \ldots \ldots \ldots \ldots .605$

A. CONDUCT OF THE SALE $\ldots \ldots \ldots \ldots \ldots \ldots \ldots \ldots$

B. NOTICE REQUIREMENTS $\ldots \ldots \ldots \ldots \ldots \ldots \ldots \ldots 806$

C. THE DUTY TO OBTAIN AN

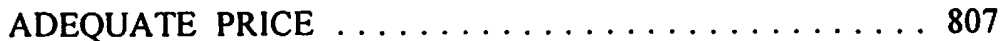

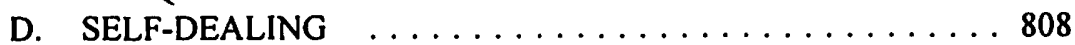

E. RIGHTS OF PURCHASERS $\ldots \ldots \ldots \ldots \ldots \ldots \ldots . \ldots 12$

VI. RESTRICTIONS ON ENFORCEMENT $\ldots \ldots \ldots \ldots \ldots \ldots \ldots 813$

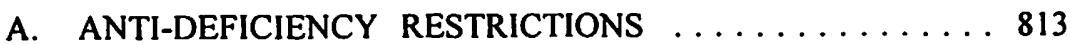

B. ADD-ON AND BLANKET

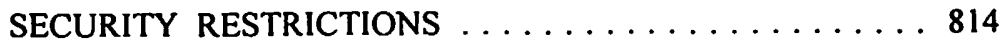

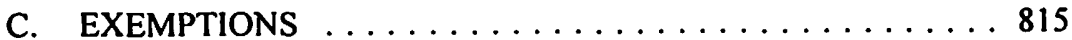

Faculty of Law, University of Alberta. I wish to thank Rick Bowes, Wilbur Bowker, Frank Buckley, Dick Dunlop, Janice Henderson-Lypkie, Geoff Ho and Michael Wylie for their comments. A preliminary version of this article was presented at the 22nd Annual Workshop on Commercial and Consumer Law in Montreal. 
D. A RATIONALIZED APPROACH $\ldots \ldots \ldots \ldots \ldots \ldots 816$

VII. JUDICIAL INTERVENTION $\ldots \ldots \ldots \ldots \ldots \ldots \ldots \ldots \ldots 817$

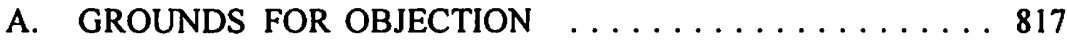

B. THE NOTICE OF OBJECTION PROCEDURE ....... 818

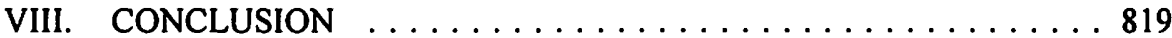

\section{INTRODUCTION}

This article is about the enforcement remedies available to a creditor against goods belonging to the debtor. The conventional approach is to discuss the enforcement remedies of secured creditors as a separate topic that has little in common with the enforcement remedies of unsecured creditors. There are two reasons why in Alberta it makes sense to examine the two enforcement systems together. In most common law jurisdictions, the enforcement remedies available to secured creditors are, and always have been, distinct from the enforcement system governing unsecured creditors. In Alberta, the evolution of enforcement remedies of creditors proceeded along a distinctly different path. From an early date, a single system of enforcement rules and procedures governed both classes of creditors. Although this fusion of the two enforcement systems has recently come to an end, one can clearly detect the imprint of the old system in the new legislative schemes. Given this unique history, it seems natural to contrast the two enforcement systems and to ask whether differences in approach are justified.

This brings us to the second reason. An unparalleled restructuring of debtor-creditor law has occurred in Alberta. The first stage was completed with the enactment of modern personal property security legislation. The focus then shifted to the reform of the provincial judgment enforcement system. Both these law reform projects were characterized by a willingness to throw off historical categories and distinctions in favour of an approach which identified a set of policy objectives and designed a system of law to implement those policies. To a large degree, the issues facing the policymaker are the same: Who should undertake the seizure? What rules should govern the disposition of the debtor's property? What property should be subject to seizure? What avenues for judicial intervention should be available? This article will explore the reasons why the enforcement system for secured creditors might rationally be designed differently from an enforcement system for judgment creditors. It also argues that where no justification can be found, a similar approach is warranted.

I will begin with a short history that will trace the emergence of the distinctive Alberta approach to enforcement remedies. I will then outline the recent legislative initiatives. Finally, I will discuss the approaches adopted in relation to the four basic components of an enforcement system: seizure, sale, restrictions on enforcement and judicial intervention. 


\section{ORIGINS OF THE OLDER SYSTEM}

The first step toward an integrated system occurred in 1914. The province was in the midst of an economic recession which lasted from 1913 to 1915.' The added uncertainty created by the onset of the first world war led to demands for a moratorium on debt recovery. Premier Sifton rejected a general moratorium ${ }^{2}$ and instead introduced The Extra-Judicial Seizures Act. ${ }^{3}$ The legislation prohibited the exercise of self-help remedies by secured creditors, landlords and other claimants. Every seizure by a secured creditor had to be undertaken by a sheriff or bailiff. The legislation also restricted the ability of both secured and unsecured creditors to remove or dispose of the property following a seizure. No sale of the goods could be undertaken except upon the order of a judge. Nor could the goods be removed from the premises without such an order.

A major reformulation of the legislation occurred in 1929,4 and the legislation was finally recast as the Seizures $A c t^{5}$ in 1933. This statute maintained the earlier policy against extra-judicial seizures, but gave the court the power to authorize a seizure by a private bailiff. ${ }^{6}$ It also relaxed the requirement that a creditor obtain a judicial order for sale through the adoption of a streamlined notice of objection procedure. ${ }^{7}$ The creditor provided the sheriff with a notice of seizure which identified the goods seized, a notice of objection to seizure and a stamped and addressed envelope. The sheriff then served these documents on the debtor at the time of seizure. If the debtor did not send in the notice of objection within fourteen days, the creditor could direct the sheriff to sell the goods by public sale. ${ }^{8}$ Somewhat greater latitude was given to a secured party. A secured party could elect to have the sheriff dispose of the property, or could elect (1995) 24 C.B.L.J. 357 at 361.

2

"Legislation Needed as Result of War is Outlined by Premier" Edmonton Bulletin (9 October 1914). As the war progressed, Alberta reversed its stand and enacted moratorium legislation. In 1916, The Volunteers and Reservists Relief Act, S.A. 1916, c. 6 was passed restricting proceedings against soldiers that protected soldiers. In 1918, The War Relief Act, S.A. 1918, c. 24 was passed, restricting proceedings against land within a city or town. This legislation was repealed following the war.

3

4 The Extra-Judicial Seizures Act Amendment Act, S.A. 1929, c. 20 established the basic notice of objection/application for removal and sale procedure. Further refinements were made in 1931 and 1932. See The Extra-Judicial Seizures Act Amendment Act, S.A. 1930, c. 11; The Extra-Judicial Seizures Act Amendment Act, S.A. 1931, c.29. S.A. 1933, c. 16. The period of intense legislative innovation then abruptly came to an end, and the statute thereafter remained largely unchanged for the next half century.

Seizures Act, R.S.A. 1980, c. S-11, s. 18, as rep. by S.A. 1994, c. C-10.5, s. 171 [hereinafter Seizures $A c t$ ]. Unless otherwise indicated, subsequent references to the Seizures $A c t$ are to this revision.

Ibid., s. 30. In the absence of a court order, the sheriff was required to sell the goods by public sale. See s. 14. 
to exercise a power of sale provided in the security agreement. ${ }^{9}$ If the debtor sent in a notice of objection, the creditor was prohibited from selling the goods unless an order for removal and sale was obtained. The burden therefore fell upon the creditor to bring an application before the court. In disposing of the application, the court could refuse the application or order the release of all or part of the goods. Alternatively, it could make an order for the removal and sale of the goods. Such an order could be suspended pending the repayment of the debt in accordance with a judicially approved repayment schedule. $^{10}$

The critical element in this legislative scheme was the use of judicial discretion to stay enforcement proceedings. The judge was expected to identify deserving debtors whose inability to pay was brought about by economic conditions beyond their control, and screen out undeserving debtors who were unwilling to pay or whose failure to pay was due to personal mismanagement or moral failing. If successful, the debtor obtained a reprieve in the form of a stay of proceedings or a rescheduling of payments rather than the writing down or cancellation of debt. "This basic approach was typical of the legislative response to economic recessions prior to the Great Depression. A series of drought area relief statutes adopted a roughly similar approach, except that it was an administrative agency rather than a judge that exercised the discretion. ${ }^{12}$

As the depression deepened, it became clear that a strategy of buying time was inadequate. The massive accumulation of debt by farmers was unserviceable. At this stage, three new strains of depression legislation emerge. The first involved debt adjustment or arrangement proceedings in which a board or court imposed a mandatory settlement that included a writing down of debt. ${ }^{13}$ The second involved legislation which extinguished the debtor's obligation to pay interest or rendered the debt

Ibid., s. 30(1)(b). See General Motors Acceptance Corp. of Canada v. Whire, [1973] 3 W.W.R. 572 (Alta. S.C.T.D.). Under s. 30(3), the creditor was required to provide the sheriff with a statutory declaration setting out the particulars of the sale and the amount realized by the sale. Ibid., s. 29(5). In 1932, The Judicature Act Amendment Act, S.A. 1932, c. 22, s. 2 was enacted (now Judicature Act, R.S.A. 1980, c. J-1, s. 18). This expanded the court's power to grant a stay and provided an additional source of jurisdiction to make orders for the payment of money in instalments.

See e.g. Edmonton Credit Co. Ltd. v. Walsh, [1942] 3 W.W.R. 438 (Alta. S.C.T.D.): practice is to give farmer debtors an extension of time to pay until December to permit them to thresh, harvest and market their crops; Re Canadian General Electric Co. Lid., [1917] 2 W.W.R. 1003 (Alta. S.C.T.D.): "the sole question for consideration on such an application is, assuming the goods to have been rightfully seized, should the removal and sale be advisable and proper under all the circumstances surrounding the case, that is, for instance, taking into consideration the state of the market, the primary object being as far as possible to avoid a sacrifice of the goods and a loss to the debtor."

12 This is the basic approach adopted by The Drought Area Relief Act, S.A. 1922, c. 43, which was later replaced by the early versions of The Debt Adjustment Act, S.A. 1923, c. 43.

13 The Debt Adjustment Act, ibid. originally required the debtor to apply for a certificate to stay proceedings. In 1933 this was changed so that the onus was upon the creditor to apply for a certificate to proceed. By 1935 the debt adjustment boards were using this power to force creditors to write down their debts. In 1941 the legislation was declared wholly ultra vires. See W. Bowker, "The Honourable Horace Harvey, Chief Justice of Alberta" (1954) 32 Can. Bar Rev. 933 at 958. 
uncollectible. ${ }^{14}$ The third attempted to limit the enforcement remedies of secured creditors. This set the stage for an unparalleled period of constitutional warfare between Aberhart's Social Credit government and Ottawa. ${ }^{15}$ Most of these provincial legislative initiatives were eventually frustrated by the exercise of the federal disallowance power or were held to be ultra vires by the courts. ${ }^{16}$ However, legislation which restricted the enforcement remedies of secured creditors was not challenged. This legislation took two forms: the extension of exemptions to secured creditors and the enactment of antideficiency legislation.

The exemptions statute, in common with those of most other Canadian common law provinces, listed several different categories of property that were exempt from seizure under a writ of execution. The statute did not apply to seizures of collateral by secured creditors. In 1935, the Exemptions $A c t^{17}$ was amended by extending these exemptions to goods taken as collateral under a chattel mortgage. This change did not affect all secured creditors. Sellers who sold their goods under conditional sales agreements were not subject to the exemptions. This was in accord with the general policy of the statute towards sellers, since the statute provided an exception to the exemption under which sellers could proceed against exempt goods which they had sold to the debtor in order to satisfy a judgment for the unpaid purchase price. $^{18}$

Anti-deficiency legislation was widely adopted in the West during this period, and was primarily directed towards land mortgages. ${ }^{19}$ However, the purchase of farm machinery also contributed to the accumulation of debt, ${ }^{20}$ and anti-deficiency legislation covering personal property was enacted in 1942. ${ }^{21}$ This "seize or sue" legislation forced an election of remedies by sellers who took conditional sales agreements in the goods they sold. The seller could enforce its security interest in the goods. This prevented the seller from suing for any deficiency. Alternatively, the seller could waive its security and proceed as an unsecured creditor. But in doing so the

14 This included attempts to render interest uncollectible and amendments to the limitations statute that barred claims unless new agreements were entered into. See J.R. Mallory, Social Credit and the Federal Power in Canada (Toronto: University of Toronto Press, 1954) at 100-105.

is See Mallory, ibid. at 91-122.

16 See W. Bowker, "Fifty-five Years at the Alberta Bar: George Hobson Steer, Q.C." (1982) 20 Alta. L. Rev. 242 at 262-267.

17 The Exemptions Act Amendment Act, 1935, S.A. 1935, c. 24.

18 Exemptions Act, R.S.A. 1980, c. E-15, s. 4, as rep. by S.A. 1994, c. C-10.5, s. 171.

19 The anti-deficiency legislation concerning land was first introduced in 1939 in Alberta by The Judicature Amendment Act, S.A. 1939, c. 85. Anti-deficiency legislation governing land is discussed in Alberta Law Reform Institute, Mortgage Remedies in Alberta (Report for Discussion No. 9) (Edmonton: Alberta Law Reform Institute, 1991).

20 Debt arising out of the purchase of farm machinery accounted for over 15 percent of the total estimated debt of $\$ 317.8$ million carried by Alberta farmers in 1931: The Case for Alberta (Edmonton: King's Printer, 1938) at 118.

21 These provisions were introduced in 1942 in An Act to Amend the Conditional Sales Act, S.A. 1942, c. 52 and now appear in Ss. 47-50 of the Law of Property Act, R.S.A. 1980, c. L-8, as re-en. 1988 , c. P-4.05, s. 87. 
creditor could not instruct seizure of the goods sold, since this will result in the extinguishment of the debt. ${ }^{22}$

We may observe, at this point, the remarkable degree of uniformity in the remedies available to creditors. Essentially the same system for enforcement applied to secured and unsecured creditors. ${ }^{23}$ In each case, the seizure had to be undertaken by a sheriff or bailiff. The same notice of objection procedure was available to the debtor. A court applied the same criteria in deciding whether to grant relief to the debtor. Although a secured creditor retained a right to sell collateral if its security agreement created such a right, the debtor could block the sale by sending in the notice of objection. Thereafter, a court order was required before a sale could proceed. In addition, the same basic exemptions policy applied to both secured and unsecured creditors. The exemptions applied to both secured and unsecured creditors, but did not affect sellers who enforced their claims against the goods sold in order to satisfy a claim for the unpaid purchase price of the goods. ${ }^{24}$

\section{MODERN REFORM OF THE LAW}

Debtor-creditor law in Alberta has undergone a radical reshaping within the last decade. The law of secured credit was substantially reformulated upon the coming into force of the Personal Property Security Act ${ }^{25}$ on October 1, 1990. Judgment enforcement law underwent a similar restructuring upon the coming into force of the Civil Enforcement $\mathrm{Act}^{26}$ on January 1,1996. These reform measures brought to an end the formal integration of the two enforcement systems that existed under the Seizures Act. The enforcement remedies of secured and unsecured creditors are now governed by two different statutory schemes. Although the enforcement systems are now separate, many features are still shared. Some of these attributes were simply carried over from the earlier system. For example, the restriction against the exercise of self-help remedies in seizing goods has been retained and extended. New features introduced in the PPSA have subsequently influenced the design of the $C E A$. In particular, there is a strong family resemblance between many of the enforcement procedures in the PPSA and those in the CEA.

The operation of the provisions is described in greater detail in R.C.C. Cuming \& R.J. Wood, Alberta Personal Property Security Act Handbook, 2d ed. (Toronto: Carswell, 1993) at 406-48. The enforcement system of the Seizures $A c t$ was incorporated by reference by several nonpossessory lien statutes such as the Garagemen's Lien Act, R.S.A. 1980, c. G-1. However, statutory and common law possessory liens are generally governed by separate statutory schemes which usually give the lien claimant the right to sell the goods by public auction. See generally R.J. Wood \& M.I. Wylie, "Non-Consensual Security Interests in Personal Property" (1992) 30 Alta. L. Rev. 1055.

In one respect, the seller who sold on unsecured credit terms was treated more favourably than the secured seller. The former could move against the goods sold and also against any other nonexempt assets. The latter had to make an election between enforcement against the goods and enforcement against the other non-exempt assets.

26 S.A. 1994, c. C-10.5 as am. by S.A. 1994, c. 23 [hereinafter $C E A$ ]. 


\section{A. THE REFORM OF PERSONAL PROPERTY SECURITY LAW}

Although the PPSA significantly changed the rules governing the enforcement of security interests, this was not the primary reason for its enactment. Financial institutions which were familiar with the operation of similar legislation in other provinces were strongly in favour of reform, as it significantly simplified their secured credit granting procedures. Another factor, which explains the government's interest in reform, was the desire to exploit advances in information technology. The PPSA offered an ideal legislative environment within which computerization of the registry system might occur. The earlier chattel security registry statutes were based upon a document filing system that required the storage of the documents at the public registries. Although there had been some movement towards the idea of a single registry and a single set of registration rules, ${ }^{27}$ it was unlikely that this ideal could ever have been realized within the confines of the earlier system. In contrast, the PPSA registry uses a notice filing system under which only bare details are provided. This makes computerization of the registry easier, since there is far less information that must be captured in creating a computer database.

The Alberta PPSA was based upon a model Act that had been drafted by an interprovincial committee. ${ }^{28}$ The model $A c t$ provided a convenient legislative template for jurisdictions that wished to reform their chattel security law. This package included a reformed system of enforcement remedies contained in Part 5 of the Act. Part 5 of the Act was premised on the traditional notion that secured creditors should be entitled to exercise self-help remedies in enforcing their claims against the collateral. Implementation of the PPSA in Alberta meant that a policy decision had to be made concerning the extent to which the structure of the model PPSA should be modified by bringing into it procedural elements of the older system. It was ultimately decided that the prohibition on private seizures should be maintained, but that the notice of objection system should not be carried forward into the $P P S A .{ }^{29}$ Enforcement proceedings under security interests were excluded from the scope of the Seizures Act. ${ }^{30}$ Instead, the enforcement remedies of secured creditors would be governed by Part 5 of the PPSA, which was modified from the model $A c t$ by adding the requirement that a sheriff conduct a seizure of collateral. ${ }^{31}$

The Chattel Security Registries Act, S.A. 1966, c. 12 created a central registry. In 1983, this system was computerized and a notice filing feature (called a financial interest statement) was adopted. See Chattel Security Registries Act, S.A. 1983, c. C-7.I. The system nevertheless remained a document filing system at heart, since the security agreement was required to be submitted for registration. This hybrid system was implemented in order to provide an easier transition to the PPSA.

For a history of these developments sec Cuming \& Wood, supra note 22 at 2-4.

See R.C.C. Cuming, "Alberta Moves Toward Enactment of a Personal Property Security Act" (1985) 11 C.B.L.J. 82 at 88-90.

R.S.A. 1980, c. S-11, s. 2(a), as am. by S.A. 1988, c. P-4.05, s. 97.

PPSA, s. 58(2), as rep. by S.A. 1994, c. C-10.5, s. 148(8). 
Although the prohibition against private seizures was retained, ${ }^{32}$ the practice of sheriffs who conducted such seizures changed dramatically. Prior to the PPSA, the sheriff would typically leave the goods with the debtor, and would await further instruction to sell from the creditor in the event that a notice of objection was not sent. Under the $P P S A$, the sheriff normally removed the goods and immediately turned them over to the secured creditor unless there was some special reason for not doing so. ${ }^{33}$ This change was a result of the elimination of the notice of objection procedure. The underlying assumption under the Seizures $A c t$ was that a debtor was entitled to maintain the status quo until given an opportunity to appear before a court. This assumption no longer held under the PPSA. Although the court had the power to order a stay of enforcement proceedings, the burden was on the debtor to apply to the court for relief.

\section{B. THE REFORM OF JUDGMENT ENFORCEMENT LAW}

It was widely agreed that Canadian judgment enforcement law was in need of reform. It was also reasonably clear what direction the reform should take. Several law reform bodies had published extensive reports which provided a blueprint for legislative revision. ${ }^{34}$ Despite this consensus, most provincial governments were unwilling to make major commitments of legislative time and administrative resources in implementing such programs of "technical law reform."

Events in Alberta unfolded differently. The Alberta Law Reform Institute in March of 1991 published its Enforcement of Money Judgments Report. ${ }^{35}$ This was the culmination of one of the longest and largest projects ever undertaken by the Institute. The proposals in the Report were then reviewed by a joint legislative review committee of the Canadian Bar Association (Alberta Branch) and the Law Society of Alberta. A discussion draft was circulated by the Alberta Attorney General for comments in July of 1994. Bill 49 was introduced on October 20, 1994 and was enacted as the Civil Enforcement Act on November 10, 1994.

Seizures by private bailiff were permitted if the creditor obtained a court order authorizing it pursuant to $s .18$ of the Seizures $A c t$. There appears to have been a growing practice of secured parties obtaining such court ordered appointments prior to the coming into force of the CEA. The sheriff had the power to remove the goods under s. 31(1) of the Seizures Act if the sheriff believed that it was necessary or advisable to do so.

34 The British Columbia Law Reform Commission published the following reports: The Altachment of Debts Act (Report No. 39) (Vancouver: BCLRC, 1978); Execution Against Land (Report No. 40) (Vancouver: BCLRC, 1978); The Creditors' Relief Legislation: A New Approach (Report No. 42) (Vancouver: BCLRC, 1979); Execulion Against Shares (Report No. 116) (Vancouver: BCLRC, 1991). The Ontario Law Reform Commission in 1981 published its Report on the Enforcement of Judgment Debts and Related Matters (Report No. 46), vols. I-III (Toronto: OLRC, 1981). New Brunswick in 1976 and 1985 published the following reform proposals: Consumer Protection Project Law Reform Division, New Brunswick Justice Dept., Legal Remedies of the Unsecured Creditor After Judgment (Third Report of the Consumer Protection Project), vol. II (Fredericton: New Brunswick Justice Dept., 1976); Law Reform Branch, New Brunswick Attorney General, Proposals for a System of Enforcement of Judgment Debts (Fredericton: New Brunswick Attorney General, 1985).

35 Alberta Law Reform Institute, Enforcement of Money Judgments (Report No. 61) (Edmonton: Alberta Law Reform Institute, 1991). 
Considering the remarkable speed with which the bill was drafted, introduced and passed, it is clear that it must have been assigned a high government priority. This was at a time when the government was engaged in a major restructuring of the province's finances that entailed massive cutbacks in social spending. Why did the Klein government, in the midst of a radical program of deregulation and deficit elimination, embrace such a politically mundane topic? It would appear that the government's primary interest was not in reforming the substantive law, but in privatizing the seizure activities of the sheriff. The perceived advantages were described as follows:

\begin{abstract}
One of the main principles or aspects of this Bill, Mr Speaker, is to privatize the seizure activities of the sheriff's office. Sheriff's seizures are conducted by bailiff's under contract, and their privatization would be a further extension of this and will provide business opportunities for the private sector, reduce costs to the government, and improve delivery of services to creditors by allowing value-added services and eliminating duplication. The privatization would shift the focus of the sheriff's office from actually conducting seizure to conducting reviews to ensure that the integrity of the justice system is not compromised. This shift in focus will require a much smaller staff complement and will provide the sheriff with a clear mandate over most seizures under provincial jurisdiction and the authority to review any such seizures that are conducted illegally or unethically. ${ }^{36}$
\end{abstract}

This does not fully explain the genesis of the CEA. Privatization of the sheriff's functions could have been carried out without reforming the substantive law. Indeed, it was accomplished in British Columbia by way of a minor legislative amendment. ${ }^{37}$ There are several reasons why a major initiative might have been seen as desirable. The privatization issue had the potential to generate considerable political controversy. ${ }^{38}$ This controversy could be dampened by including it as a smaller part of a major reform initiative that had been endorsed by the Alberta Law Reform Institute. ${ }^{39}$ Secondly, the reform initiatives eliminated many of the inefficiencies of the older enforcement system,

Legislative Assembly, Alberta Hansard (24 October 1994) at 2533-34 (speech of Mr. Durnford) [hereinafter Alberta Hansard]. Three further advantages were mentioned. The legislation eliminated existing duplication in registry functions between the sheriff's office and the personal property registry. It streamlined debt collection procedures in Alberta and eliminated unnecessary loopholes in order to reduce the risk of uncollectible debts. It also eliminated the government's exposure to liability for negligent or improper seizures.

37 In British Columbia, the privatization of the sheriff's enforcement activities was accomplished through a very short amendment to the Attorney General Statutes Amendment Act, S.B.C. 1992, c. 31 , s. 19. This amended s. 2.1 (1) of the Sheriff Act, R.S.B.C. 1979, c. 386 by providing that the minister may appoint a person as court bailiff to exercise the powers of a sheriff for the purpose of enforcing writs. The following year the Miscellaneous Statutes Amendment Act (No.2), S.B.C. 1993, c. 55, s. 25 added s. $2.1(1.1)$ to the Sheriff Act. This provided that a court bailiff is deemed to be a sheriff for the purposes of any amendment that confers any powers, rights or duties in respect of any civil execution proceedings.

3n This was clearly the most controversial issue in the legislative debates where some opposition members argued that the privatization initiative would produce overly aggressive collection practices by civil enforcement agencies. See Alberta Hansard (1994) at 2535, 2622-23, and 2947. Members of the opposition expressed concern that the legislation would produce "Kneecappers $\mathbf{R}$ Us" and "Repos R Us." The names of the companies that have entered into agreements with the Sheriff to operate as civil enforcement agencies are considerably less colourful. 
and this would make it easier to attract private sector participants. ${ }^{40}$ Finally, the reform project seemed to fit into the government's "deregulation action plan," which directed its departments to "recommend revision, reduction or outright elimination of unnecessary rules and regulations." ${ }^{.41}$

\section{AMENDMENT OF THE DEPRESSION STATUTES}

The final aspect in the reform of enforcement law in Alberta concerns the revision of the Depression era restrictions on enforcement. The first change occurred near the end of a deep recession from 1980 to 1984 which followed the boom years of the 1960 s and 70 s. During this period, the Getty government introduced several bills designed to enact new anti-deficiency legislation in favour of farmers and homeowners, and encountered considerable opposition from lenders. ${ }^{42}$ In 1984, the government also decided to raise the monetary limits associated with several categories of exempt property. ${ }^{43}$ These had not been changed in decades, and which had been seriously eroded by the effects of inflation. During the committee stage, an amendment to the bill was introduced. This amendment repealed the section of the Exemptions $A c t^{44}$ which extended the exemptions to seizures under chattel mortgages. The reasons for this amendment are not recorded. One may speculate that it was introduced to defuse the opposition of institutional lenders who made their loans predominantly on a secured credit basis. Unlike the diffuse body of creditors who extended credit on an unsecured basis, the secured lenders were comprised of a small number of large financial institutions which were better able to organize an effective lobbying campaign.

The anti-deficiency provisions of the Law of Property $\mathrm{Act}^{45}$ were amended upon the coming into force of the PPSA. The amendment was needed because of the different terminology used in the PPSA. However, a major substantive change was also introduced. The original provision applied to all categories of debtors, but provided that a corporate debtor was permitted to waive the benefits of the statute. ${ }^{46}$ The redrafted provision limited its application to security interests in consumer goods. As a result, the anti-deficiency protection which began predominantly as a farm protection law ended up as a consumer protection measure.

4)

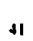

41

For an overview of these reforms, see R.J. Wood, "The Reform of Judgment Enforcement Law in Alberta" (1995) 25 C.B.L.J. 110.

The government's "deregulation action plan" is described in the Speech from the Throne. See Alberta Hansard (31 August 1993) at 7-8. The CEA fit into the government's deregulation agenda because three statutes were repealed, and a single statute was enacted in their place.

Mortgage Remedies in Alberta, supra note 19 at 31-34.

Alberta Hansard (28 May 1984) at 1097-99.

R.S.A. 1980, c. E-15, s. 3. The provision did not operate in exactly the same way as a seizure under execution. It was held that the goods must fall within an exempt category both at the time of execution of the chattel mortgage and at the time of seizure. Furthermore, the debtor had the onus of proving that the goods were exempt. See Winnicky v. Grande Prairie \& District Savings \& Credit Union Lid., [1976] I W.W.R. 80 (Alta. S.C.T.D.).

R.S.A. 1980 , c. L-8, ss. 47-55, re-en. by S.A. 1988, c. P-4.05, s.87.

In practice, virtually every security agreement contained such a waiver clause where a corporate debtor was involved. 


\section{SEIZURE}

In other provinces, secured parties have the right to exercise their self-help remedies against the collateral in the event of a default. From an early date, Alberta has adopted a more restricted approach to the exercise of self-help remedies by secured parties. The absence of sharp dichotomy between these two types of seizures produces a greater similarity in the legal rules which govern such matters as the power of bailiffs and liability for wrongful seizure. Despite these similarities, there remain some important differences in the function and operation of the rules governing seizure under the two enforcement systems.

\section{A. THE LEGAL FRAMEWORK}

Part 2 of the $C E A$ provides the legislative framework for the privatization of the sheriff's enforcement functions. The sheriff is empowered to enter into contracts on behalf of the Crown authorizing the operation of civil enforcement agencies. ${ }^{47}$ Civil enforcement agencies are given the exclusive right to carry out seizures, sales and distributions under writ proceedings, seizures under a right of distress and evictions. ${ }^{48}$ The term "distress" is defined very broadly so as to include seizures under a security interest governed by the $P P S A$, seizures by a lessor of personal property, a landlord's right to distrain for unpaid rent, and any other right to take possession out of the possession of another person. ${ }^{49}$ The service contracts set out the terms and conditions under which the agency operates, including insurance, bonding, reporting and auditing requirements. ${ }^{30}$

The actual conduct of a seizure or eviction must be undertaken by a civil enforcement bailiff, who must be employed directly by an enforcement agency or engaged under contract to the agency. ${ }^{51}$ Civil enforcement bailiffs are appointed by the sheriff after having successfully met training and other qualifications. ${ }^{52}$ The $C E A$ withdraws the power previously given to courts to appoint private bailiffs, ${ }^{53}$ but does not operate to restrict the powers of receivers. ${ }^{54}$ The $C E A$ gives bailiffs the statutory authority to conduct seizures, and sets out a number of rules regarding the entry into premises and the use of force. ${ }^{5 s}$

Part 2 of the $C E A$ also contains provisions setting out the bailiffs' power of seizure and other related matters. These rules apply to seizures under writ proceedings and as well apply to seizures under security agreements and repossessions under chattel leases.

17 CEA, s. 9(1).

48 Ibid., s. 9(3).

49 lbid., s. I(1)(1).

so

Alberta Justice, Civil Enforcement Agencies - Request for Proposal (Edmonton: Alberta Justice, 1994).

si $\quad C E A$, s. 9(4).

32 Civil Enforcement Regulation, Alta. Reg. 276/95, ss. 23, 25.

33 $\quad C E A$, s. 9(5).

st Ibid., ss. 9(8), 85

ss Ibid., ss. 10, 12. 
Both the $C E A$ and the PPSA have an additional set of provisions which govern seizures. As a result, the rules governing seizure will vary on some matters depending upon the type of enforcement proceedings that are involved.

\section{The Power to Enter Premises and Seize Goods}

At common law, the sheriff's right to seize goods under a writ of execution was separate and distinct from a secured party's right to seize collateral pursuant to a security interest. The secured party's right to seize collateral arose out of the secured party's interest in the goods or by virtue of a contractual right to take possession of the collateral. ${ }^{56}$ The secured party was permitted to repossess the goods so long as it did not constitute a breach of the peace. ${ }^{57}$ If the secured party could not obtain the goods peaceably, the secured party could not use force, but had to resort to the courts to obtain possession.

The sheriff's right to gain entry in order to seize goods derived from the duty to execute civil process, ${ }^{58}$ and was broader in scope than the secured party's right to repossess. ${ }^{59}$ The primary limitation was that the sheriff could not gain entry to the debtor's dwelling by force against the will of the debtor. ${ }^{60}$ The sheriff was permitted to enter if the door was open or unlocked, ${ }^{61}$ but was not permitted to break down a locked door or push aside a debtor who was attempting to bar entry. ${ }^{62}$ However, once lawfully inside the sheriff could break open inner doors, cupboards and other containers. ${ }^{63}$ The debtor's privilege only extended to a dwelling, and the sheriff could therefore use force to gain access to other buildings. ${ }^{64}$

The distinction between the sheriff's right to seize and a secured party's right to repossess became clouded under the Seizures Act. Seizures pursuant to a security agreement had to be undertaken by the sheriff. However, in conducting the seizure the sheriff did not act as an officer of the court but as agent of the secured party. ${ }^{65}$ This

Prior to the PPSA, this depended upon the kind of security device that was involved. This right to take possession did not need to be bargained for in the case of a legal mortgage, but had to be included as an express or implied term in a conditional sales agreement. See Humphrey Motors Lid. v. Ells, [1935] S.C.R. 249.

R. v. Doucette, [1960] O.R. 407 (C.A.). See also D. Paciocco, "Personal Property Security Act Repossession: The Risk and the Remedy" in Springman \& Gertner, eds., Debtor-Creditor Law: Practice and Doctrine (Toronto: Butterworths, 1985) 365.

G. Turiff \& E. Edinger, The Office of the Sheriff, (Study Paper) (Vancouver: Law Reform Commission of British Columbia, 1983) at 132.

See generally Turiff \& Edinger, ibid. at 141-45; C.R.B. Dunlop, Creditor-Debtor Law in Canada, 2d ed. (Toronto: Carswell, 1995) at 299-305.

Semayne's Case (1604), 77 E.R. 194 (K.B.). See also W.F. Foster \& J.E. Magnet, "The Law of Forcible Entry" (1977) 15 Alta. L. Rev. 271.

6) Southam v. Smout, [1964] 3 All E.R. 104 (C.A.).

(2. Vaughan v. McKenzie, [1969] I Q.B. 557 (C.A.).

(1) Kerbey v. Denby (1836), 150 E.R. 463.

(4) Hodder v. Williams, [1895] 2 Q.B. 663 (C.A.).

is Lipsey v. Royal Bank of Canada, [1919] 2 W.W.R. 979 (Alta. S.C.T.D.); In re Scragg (1924), 5 C.B.R. 398 (Alta. S.C.T.D.); Canadian Imperial Bank of Commerce v. Delta Masonry \& Concrete Lid. and Pfaff (1985), 41 Alta. L.R. (2d) 48 (M.C.). 
suggests that the sheriff was able to exercise only the more limited powers of a secured party in undertaking the seizure. On the other hand, s. 23 of the Seizures Act did not draw a distinction between the two kinds of seizures. This section gave the sheriff the power to break open the door of a building other than a private dwelling, and upon obtaining an order of the court the power to break down the door of a private dwelling.

The $C E A$ clarifies this matter. A civil enforcement bailiff is given the same powers regardless of the type of seizure that is involved. Section 13 of the $C E A$ sets out the powers of bailiffs in conducting such seizures. For the most part, it is a codification of the common law power of the sheriff to carry out a seizure under a writ. There is one change concerning third party premises. At common law, a sheriff who entered into a third party's residence was justified only if goods of the debtor were actually discovered there. ${ }^{66}$ The $C E A$ provides that a civil enforcement bailiff may enter third party premises if there are reasonable grounds for believing that personal property of the debtor is located there, but that a court order is required whenever entry to the third party premises is refused or if force is needed for the purposes of gaining access. ${ }^{67}$

\section{The Requirements for a Valid Seizure}

Although there is no longer a distinction drawn between a bailiff's power of seizure under writ proceedings and a bailiff's power of seizure under a security agreement, the rules governing other aspects of seizure have not been merged. The rules governing seizures under security agreements are found in s. 58 of the PPSA, while the rules governing seizure under writ proceedings are located in Part 5 of the $C E A$. Although there are some surface similarities in these rules, a closer analysis reveals that they are conceptually distinct.

At common law, there were two requirements for effecting seizure under a writ of execution. ${ }^{68}$ First, the sheriff had to go to the location where the goods were located. Although the sheriff did not have to physically make contact with the goods, the sheriff had to be in a position to lay hands on the goods. Second, the sheriff had to take some positive steps to communicate that a seizure was made. These common law requirements were supplemented by additional statutory requirements set out in the Seizures $A c t^{69}$ which required that the seizure documents ${ }^{70}$ be served on an adult member of the debtor's household, attached to the goods or posted in a conspicuous place on the premises. The seizure of the goods and the service of the seizure documents had to be contemporaneous in order to constitute a valid seizure. ${ }^{11}$

Southam v. Smout, supra note 61 at 109.

$C E A$, s. 13(2)(a)(ii), (c).

Dodd v. Vail (1913), 9 D.L.R. 534, affd 10 D.L.R. 694 (Sask. C.A.); United Farmers of Alberla Co-operative Lid. v. Foothills Sand \& Gravel Lid., [1985] 5 W.W.R. 83 (Alta. Q.B.).

See s. 26.

The seizure documents included a notice of seizure describing the goods and notice of objection. United Farmers of Alberta Co-operative Lid. v. Foothills Sand \& Gravel Lid., supra note 68. 
Section 45 of the $C E A$ retains this system with some modification. There is an additional requirement that the seizure documents include an exemption notice which describes the exemptions and the objection procedure. ${ }^{72}$ There is also an added procedural requirement. In the event that the seizure documents are attached to the goods or posted on the premises, the seizure documents must be served on the debtor as soon as practicable. ${ }^{73}$ If the creditor cannot do so, the seizure is valid, but the creditor must proceed in the same manner as if the notice of objection had been filed. $^{74}$

Section 58(6) of the PPSA sets out the rules governing the requirements for seizure under a PPSA security agreement. There are four alternative methods through which a civil enforcement bailiff may make a seizure of property. Seizure may be effected by physically taking possession of the collateral; giving a notice of seizure to the debtor; posting a notice of seizure in a conspicuous place on the premises; or affixing a sticker to the goods in the prescribed form. Consequently, there is no requirement that a civil enforcement bailiff complete a notice of seizure if the bailiff takes physical possession of them. This, no doubt, stems from the fact that there is no notice of objection procedure under the PPSA. The service requirement under the CEA ensures that the seizure documents are received by the debtor so that the debtor will have an opportunity to file a notice of objection in a timely manner. As there is no equivalent procedure under the PPSA, there is no pressing need to inform the debtor of the seizure.

Under the $C E A$ enforcement system, a seizure of the goods must occur before an enforcement sale can take place. ${ }^{75}$ The situation is different under the PPSA. The secured party's right of sale and right of foreclosure do not depend upon the existence of a valid seizure. ${ }^{76}$ A seizure of goods is merely a practical step which is undertaken by a secured party to facilitate the subsequent disposition of the collateral. This difference in wording of the statutes has an important consequence. In the case of writ proceedings, the validity of all subsequent enforcement measures depend upon the existence of a valid seizure. Under the $P P S A$, a valid seizure is not a pre-condition that must be satisfied before further enforcement activity may occur. As a result, a debtor can not impugn a proposed sale on the ground that the seizure of the goods was invalid

Civil Enforcement Regulation, supra note 52, s. 2, Form 7.

$C E A$, s. 45(3). This added requirement only applies where the creditor has effected seizure by attaching the seizure documents to the goods or posting them on the premises. It does not alter the rule that, in any other case, seizure and service of the seizure documents must be contemporaneous.

Ibid., s. 45(4).

Ibid., s. 48. This section provides a set of rules that apply to the sale of "seized property."

PPSA, s. 60 which sets out the rules and procedures pertaining to sale and s. 62 which sets out the rules and procedures pertaining to foreclosure. These provisions are conditioned on there being a default and not on the existence of a seizure of collateral. 
under the PPSA, but may do so where the seizure is invalid under writ proceedings. ${ }^{77}$

The $C E A$ creates two special seizure mechanisms that are available only under writ proceedings. A special "serial number goods" seizure mechanism permits an enforcement creditor to effect seizure by registering a notice of seizure in the Personal Property Registry and serving a notice of seizure on the debtor ${ }^{78}$ The scope of this provision has been greatly restricted by the regulations which limit its availability to exceptional circumstances. ${ }^{79}$ The $C E A$ provides a second special seizure procedure where exigible personal property is believed to be in the possession of a third party. ${ }^{80}$ A civil enforcement agency may serve a demand on the third party, who is then required to make it available to the agency. Failure to comply renders the third party liable for any pecuniary loss caused by non-compliance. The absence of similar special seizure mechanisms in the PPSA is of little consequence. The "serial number goods" seizure mechanism might be useful to enforcement creditors in circumstances where it is difficult to get to the location of the goods to effect seizure, since a seizure is a precondition for further enforcement activity. The same is not true in relation to the enforcement remedies of secured parties, and therefore secured parties do not need this special seizure mechanism. A third party demand procedure is also not required because a failure by a third party to deliver the goods to the secured party will render the third party potentially liable in an action in detinue or conversion. ${ }^{81}$

\section{Removal of the Goods}

The original Extra-Judicial Seizures Act prohibited the removal of the goods without a court order. The legislation was subsequently amended to give a sheriff the power to remove the goods if advisable to do so, but sheriffs continued to observe the practice of leaving the goods in the possession of the debtor. ${ }^{82}$ This practice ran afoul of the common law concept of abandonment of seizure. At common law, a valid seizure would come to an end if the sheriff failed to maintain possession of the goods. ${ }^{83}$ Sheriffs would attempt to obtain a bailee's undertaking from the debtor under which the debtor agreed to hold the goods as bailee of the sheriff and to surrender possession

Section $13(\mathfrak{f})$ of the CEA provides that a seizure is not invalidated by an irregularity in the procedure by which it is carried out, but a court may order a seizure discontinued under s. $13(\mathrm{~g})$ where it is satisfied that a person has been or is likely to be prejudiced by the irregularity. These provisions are unlikely to apply where there has been a failure to comply with s. 45 , since this would go to the substantive validity of the seizure rather than an irregularity in the manner in which it was carried out.

$C E A$, s. 54.

Section 8(3) of the Civil Enforcement Regulation, supra note 52 provides that the remedy is not available unless a civil enforcement agency has reasonable grounds for believing that a normal seizure would fail because the property is inaccessible due to weather conditions or the location of the property or that the costs associated with effecting a normal seizure would be unreasonable.

CEA, s. 44.

Cuming \& Wood, supra note 22 at 434-35.

The sheriff would generally attempt to obtain a bailee's undertaking from the debtor under which the debtor agreed to hold the goods as bailee of the sheriff and to surrender possession of them on demand.

Young v. Dencher, [1923] 1 W.W.R. 136 (Alta. S.C.A.D.). 
of them on demand, but it was not always possible to do so. In 1937, the Seizures Act was amended to provide that a seizure was deemed to be a continuing seizure until the sheriff by notice in writing released the seizure or until the goods were sold. ${ }^{84}$ Although this amendment did away with the necessity of obtaining a bailee's undertaking, sheriffs typically attempted to obtain such an undertaking from the debtor.

The sheriff's practice of leaving the goods with the debtor functioned somewhat like a temporary stay in enforcement. Following the seizure, the debtor was given an automatic fourteen day period during which no further enforcement steps could be taken. This period could be extended by filing a notice of objection. If this were done, no further enforcement steps could be taken until a court order for removal and sale was obtained. This had the effect of slowing down the enforcement process and extending the period during which a compromise or settlement between the debtor and creditor could be negotiated. It also tended to give the debtor more leverage in any negotiations, since the onus was upon the creditor to apply to court for an order for the removal and sale of the goods.

Both the PPSA and the $C E A$ effect a major change in policy concerning the removal of goods following seizure. The PPSA provides that the goods may be surrendered to the secured party following the seizure. ${ }^{85}$ Upon the coming into force of the PPSA, there was an immediate change in the practice of sheriffs. The sheriff would turn over possession of the goods to the secured party in all but exceptional circumstances. The $C E A$ adopts this policy as well. It is the instructing creditor who makes the decision to remove the goods or to leave them with the debtor. ${ }^{86}$ As a result, the debtor loses much of the post-seizure bargaining power that the debtor formerly enjoyed.

Section $13(\mathrm{j})$ of the $C E A$ imposes a new duty on debtors who remain in possession of seized property. Under the $C E A$, a debtor in possession holds the property as bailee for the civil enforcement bailiff or agency and must deliver it upon request at a location specified by the bailiff or agency. A failure to do so will render the debtor liable for civil contempt. Unless it is given a restricted reading by the courts, s. 13(j) will create an unprecedented obligation on the part of debtors to surrender their goods on demand. This problem is exacerbated in relation to seizures under the PPSA. The PPSA provides that a seizure can be effected merely by giving a notice of seizure to the debtor as an alternative to taking physical possession of the goods. ${ }^{87} \mathrm{~A}$ similar problem arises in relation to the special seizure mechanism provided in relation to serial number goods. ${ }^{88}$ In both cases, a notional seizure can be effected by giving notice of seizure to the debtor, and the debtor thereafter is required to surrender the goods at a location specified by the civil enforcement agency. Under the prior law, a similar obligation was imposed only if the debtor signed a bailee's undertaking. Although s. 13(i) authorizes

An Act to amend The Seizures Act, S.A. 1937, c. 21, s. 3, adding s. 25(2) to the Seizures Act. See also Jacobsen v. Feschuk (1953), 10 W.W.R. 439 (Alta. Dist. Ct.). PPSA, s. 58(10).

* CEA, ss. 12(c), 13(h). These provisions are contained in Part 2 of the $C E A$, and therefore apply to all seizures.

* $C E A$, s. 54. See also supra note 79 and accompanying text. 
the continuation of this practice, there no longer appears to be any legal advantage in doing so since a similar obligation arises automatically under $s$. 13(j) simply by virtue of a valid seizure.

\section{Liability for Wrongful Seizure}

At common law, a sheriff was under a duty to carry out execution by seizing sufficient assets to satisfy subsisting writs. The sheriff owed a duty to execution creditors to exercise due diligence in effecting seizure, and was liable for any loss caused by an unreasonable delay. ${ }^{89}$ The bailiff who actually performed the seizure was liable in trespass and conversion if goods belonging to a third party were seized, ${ }^{90}$ and was also liable to the debtor if the seizure was wrongful or excessive. ${ }^{91}$ Under English common law, the sheriff was liable for the wrongful acts of bailiffs and other subordinates in carrying out the process of execution. ${ }^{92}$ This rule was rejected in Alberta. ${ }^{93}$ The courts noted that, unlike the English sheriff who is an independent contractor responsible for the hiring of staff, the sheriff in Alberta is a public servant who has no formal control over other provincial employees. For this reason, they refused to expose the sheriff to liability for the wrongful acts of bailiffs. However, legislation also made it clear that the Crown was unwilling to accept responsibility for the acts of its servants in connection with the execution of civil process. ${ }^{94}$ An execution creditor was generally not exposed to liability for wrongful seizure. But if the execution creditor went further than instructing seizure and gave special instructions on what to seize, the execution creditor would be liable for torts committed by the bailiff in carrying out those instructions. ${ }^{95}$

The legal analysis was somewhat different in relation to a seizure pursuant to a security agreement. A sheriff was not considered to act as officer of the court, but as persona designata and agent of the instructing creditor. ${ }^{96}$ As a consequence, the secured creditor was responsible for any wrongful act of the bailiff in the conduct of the seizure. There was also some pre-PPSA authority for the view that a seizure pursuant to a security agreement could not be impugned as an excessive seizure. This was explained on the ground that the secured party had contracted for the right to seize, and therefore did not need to compare the value of the goods against the obligation secured. ${ }^{97}$ This position likely has been altered under the PPSA. A secured party is under a statutory obligation to act in good faith and in a commercially reasonable

Robinson v. Grange (1859), 18 U.C.Q.B. 260 (C.A.).

Overn v. Strand, [1931] S.C.R. 720.

Ibid. Sce also Dunlop, supra note 59 at 297-99.

Dunlop, ibid. at 288-89.

Great Northern Insurance Co. v. Young, [1917] I W.W.R. 886 (Alta. S.C.T.D.); Gunn's Pure Foods LId. v. Rae, [1934] 2 W.W.R. 108 (Alta. S.C.A.D.).

Proceedings Against the Crown Act, R.S.A. 1980, c. P-18, s. 5.

Meadow Farm Lid. v. Imperial Bank of Canada, [1922] 2 W.W.R. 909 (Alta. S.C.A.D.); Olsen v. Van Wart (1910), 13 W.L.R. 661 (Alta. S.C.T.D.).

Fraleck v. Johnstone, [1920] 3 W.W.R. 805 (Alta. S.C.T.D.). See also the sources mentioned at supra note 65.

Mandelin v. Stan Reynolds Auto Sales Lid. (1961), 31 D.L.R. (2d) 697 (Alta. S.C.T.D.). 
manner, ${ }^{98}$ and this would seem to preclude a secured party from seizing more than what is needed to satisfy the obligation secured.

The $C E A$ radically restructures the role and function of the sheriff. Civil enforcement agencies now carry the responsibility for enforcing civil process under writs. The function of the sheriff is to screen, train and monitor civil enforcement agencies and bailiffs and to investigate complaints. The role of the bailiff remains largely unchanged: a bailiff is employed by or under contract with a civil enforcement agency and carries out the actual seizure and any removal of the goods. It becomes necessary to examine how this changes the incidence of liability for wrongful seizure.

The government remains immune from liability. The $C E A$ provides that neither an agency nor a bailiff is an agent of the Crown and that the Crown is not liable for the acts of an agency or bailiff. ${ }^{99}$ Bailiffs will also continue to be liable for wrongful acts against the debtor and against third parties. The question of liability of the civil enforcement agency and of the enforcement creditor is more complex. It seems clear that civil enforcement agencies should not be given the benefit of the former rule which immunized the public service sheriff from liability for the acts of bailiffs. ${ }^{100}$ Because civil enforcement agencies have control over the hiring of their bailiffs, they should also take responsibility for their acts.

The question whether the instructing creditor should also be liable for a wrongful seizure is more difficult to resolve. In the past, a distinction was drawn between seizures under a writ and seizures pursuant to a security agreement. A secured creditor who instructed seizure was liable for the wrongful acts of a bailiff, but an execution creditor who instructed seizure was not liable unless the creditor provided special instructions or directions to the sheriff. ${ }^{101}$ There is nothing in the $C E A$ which would alter the liability of a secured party. The controversial issue is whether a civil enforcement agency should be regarded as occupying the same role as a sheriff under prior law, or if it should be considered to be acting as agent of the enforcement creditor. The rule that formerly governed was premised on the notion that the sheriff exercised an independence and freedom of action under which the sheriff was obliged to comply with the original direction to execute but was not required to follow any specific directions. ${ }^{102}$ Civil enforcement agencies do not exercise a similar independence of action, and therefore the instructing creditor should also be responsible for wrongful acts. ${ }^{103}$

There also appears to be a change in the liability associated with a seizure of exempt goods. The now repealed Exemptions Act prohibited a person from seizing any goods that appeared to be exempt from seizure, but relieved that person from liability for a

PPSA, s. 66(1).

$C E A$, s. 11.

See sources mentioned at supra note 93.

See sources mentioned at supra note 95 .

Turiff \& Edinger, supra note 58 at 132-33.

Section 12(c) of the CEA provides that an agency is bound to carry out any written instruction for a duty or function that is permitted pursuant to the $C E A$. 
seizure of exempt property if he or she acted in good faith. ${ }^{104}$ If it was impracticable to separate the exempt property at the time of seizure, the sheriff was empowered to seize all of the goods and hold them until such an ascertainment could be made. ${ }^{105}$ The $C E A$ retains the view that the exemptions are a right and not merely a privilege by making it abundantly clear that the exemptions cannot be waived. ${ }^{106}$ As well, the seizure documents now include a notice setting out the exemptions to which the debtor may be entitled. ${ }^{107}$ However, there is no counterpart to the legislation that insulated the sheriff from liability resulting from a good faith seizure of exempt property. This strongly suggests that civil enforcement agencies will be liable for loss caused by a seizure of exempt property. In order to reduce the exposure to loss, an agency might employ a strategy of leaving the goods in the possession of the debtor for the fifteen day period following the seizure in order to give the debtor an opportunity to raise the issue of exemptions. This would not transform an unlawful seizure of exempt property into a lawful one, ${ }^{108}$ but it would limit the damages that could be claimed by the debtor.

As in the past, the use of the indemnity passes some of the exposure to liability to the instructing creditor. ${ }^{109}$ The $C E A$ provides that a civil enforcement agency can refuse to act if an indemnity is not provided, ${ }^{110}$ but the indemnity cannot cover negligence or wilful misconduct by a civil enforcement agency."' A civil enforcement agency does not possess a monopoly on enforcement activity within the service area, and it is possible that some creditors will have the bargaining power to insist that the civil enforcement agency take the risk of loss. The relationship between the instructing creditor and the civil enforcement agency has also changed. Their relationship is now essentially a contractual one and it remains to be seen if this will modify the duties or the standards of care that formerly governed the relationship between the sheriff and the instructing creditor.

\section{B. SELF-HELP REMEDIES OF CREDITORS}

Alberta debtor-creditor law has always displayed a greater willingness to employ a similar set of principles to the enforcement remedies of both secured and unsecured creditors. The Seizures Act adopted the judgment enforcement system as the dominant model, and required secured creditors to conform to its approach. This entailed the loss of the secured creditors' self-help remedy of repossession of the goods. Although this is consistent with the general tendency in the law to substitute judicial processes in 
favour of self-help remedies, ${ }^{112}$ one can equally imagine a system under which the enforcement remedies of secured creditors is adopted as the dominant model so that a judgment creditor is given the remedies of a secured creditor against the exigible property of the debtor. I shall argue that there are compelling reasons against the extension of self-help remedies to judgment creditors. I shall also argue that while the case for restricting self-help remedies of secured creditors is not as strong, there are valid social policy objectives that can be achieved through regulation and that the outcome will depend upon what values the legislature wishes to pursue.

In order to analyze this issue it is necessary to briefly discuss the advantages and disadvantages of the exercise of self-help remedies of creditors. The obvious advantage to creditors is that they obtain a cheap and summary method of pursuing their claims against debtors. It is possible that this may benefit non-defaulting debtors to the extent that the superior remedies will result in a greater availability of credit. The disadvantage is that it may lead to illegal or abusive repossession tactics by creditors, and creates greater opportunities for confrontation between private citizens. Illegal or abusive repossession tactics may harm others who are not parties to the credit transaction. Late night repossession of automobiles or the use of physical intimidation impose external costs on third parties by threatening the security of their neighbourhood and the integrity of their community.

The concern over illegal or abusive tactics applies to both secured and unsecured creditors. However, the magnitude of the risk will differ depending upon the class of creditor involved. The incidence of one time participants is greater in the case of judgment enforcement. They will not be affected by reputational concerns, and there may be a greater level of animosity between the parties which may spill over into the exercise of enforcement remedies. There is also the risk of improper seizure caused by inexperience. ${ }^{113}$ The extension of self-help remedies to judgment creditors would therefore produce an intolerable risk of precipitous action and confrontation.

The exercise of self-help remedies of secured creditors is less likely to be affected by similar factors. The vast majority of secured creditors are financial institutions or major credit-granting corporations who are in the business of extending credit. ${ }^{114}$

F.H. Lawson, Remedies of English Law, 2d ed. (Middlesex, England: Penguin Books, 1980). A persistent theme in history has been the "continuous attempt by political societies to suppress selfhelp remedies and substitute for it judicial processes," ibid. at 25.

An empirical study indicated that between 1981 and 1982, over 47 percent of the judgments obtained were for amounts not exceeding \$1004. See Institute of Law Research and Reform, The Operation of the Unsecured Creditors' Remedies System in Alberta (Research Paper No. 160) (Edmonton: Institute of Law Research and Reform, 1986) at 60-64. Statistics from the sheriff's office indicate that in 1991 there were 9,579 writs filed in the judicial district of Alberta of which 1597 ( 16.67 percent) were by individuals.

114 The use of the secured party code is a good measure of the extent to which secured credit is utilized by repeat players. The secured party code is used by high volume registrants that reduces the need to input the name and address of the secured party for every registration. Registry statistics indicate that during the period September 1, 1991 to August 31, 1992 there were 378,701 registrations of security agreements of which 329,493 ( 87 percent) were by secured party code. If anything this underestimates the percentage of repeat players since some financial institutions 
They are repeat players who may suffer adverse reputational consequences by pursuing an overly aggressive approach to enforcement. A secured creditor will typically contract out the seizure function or have in-house staff carry out the seizures. There is less likelihood of an illegal seizure occurring as a result of inexperience on the part of the creditor. It is also less likely that abusive repossession tactics will occur as a result of personal animosity towards the debtor.

Despite these potential checks on secured creditor misbehaviour, there are a number of factors that support the restriction against self-help remedies. Creditors may seek to minimize any damage to their reputation as "friendly" credit-granters by contracting out the repossessions to third parties. ${ }^{115}$ There is also a significant risk that a secured creditor or its agent will make a calculated decision to use oppressive tactics if the benefits of doing so exceed the costs. As a group, defaulting debtors are much less likely to be in a financial or psychological position to seek legal redress for wrongful seizure. ${ }^{116}$ In many cases, the conduct may go beyond the standard of behaviour expected in the marketplace, and yet it may not be sufficient to found a cause of action in tort. In this respect, the reasons for regulating self-help repossessory remedies are similar to those that justify the regulation of the practices of debt collection agencies. ${ }^{117}$ Regulation therefore works along two dimensions. First, it prohibits certain practices which at common law were not illegal but which are considered to involve unwarranted harassment. Second, it provides the debtor with a cheap but effective procedure for complaining about abusive collection practices which does not involve the expense of commencing legal action.

Although there are sound policy objectives that support the regulation of a secured party's repossessory remedies, there is also a practical economic reason why the prohibition of self-help remedies was retained and expanded in the CEA. Nearly 80 percent of the seizures of personal property in the province were made pursuant to distress proceedings (seizures pursuant to security agreements, non-possessory liens and distraint for unpaid rent) rather than pursuant to writ proceedings. ${ }^{118}$ In privatizing the sheriff's function, the government had to provide an assurance to its private sector partners that there would be a sufficiently large volume of business. It is doubtful whether privatization would have been economically viable if distress proceedings were excluded from the package of services.

with a lower volume may not have secured party codes.

A.A. Leff, "Injury, Ignorance and Spite - The Dynamics of Coercive Collection" (1970) 80 Yale L.J. I at 35-36.

W.C. Whitford, "A Critique of the Consumer Credit Collection System" [1979] Wisc. L. Rev. 1046 at 1064-66.

Collection Practices Act, R.S.A. 1980, c. C-17. See also Alberta Law Reform Institute, Debt Collection Practices (Report No. 42) (Edmonton: Alberta Law Reform Institute, 1984).

Civil Enforcement Agencies - Request for Proposal, supra note 50, Fig 2.3.2 (Summary of Sheriff

Seizure Activities by Service Area). 


\section{THE EFFECT OF PRIVATIZATION}

The Klein government thought it desirable to privatize the operational activities of sheriffs in order to achieve a substantial cost-savings to the government and that this would assist it in its deficit-reduction efforts. ${ }^{119}$ It also believed that privatization would produce new business opportunities for the private sector and provide the possibility of increased efficiencies and value-added services. It seems likely that the $C E A$ will achieve a cost-savings to government. Under the pre-CEA system, an enforcing creditor who instructed seizure did not have to pay the full cost of that activity. The system therefore provided a public subsidy of debt enforcement activity. However, privatization was not the only method by which this could be achieved. The fees chargeable by the sheriff to the enforcement creditor might simply have been increased in order to cover the operating costs of the debt enforcement system.

Privatization was attractive primarily because of the government's belief that private firms are able to outperform public agencies in providing efficient, effective and innovative services. The obvious concern with privatization of seizure activity is that private enforcement agencies will identify too closely with the interests of their customers (the instructing creditors). Civil enforcement agencies are in competition with other civil enforcement agencies for customers (enforcing creditors). Enforcing creditors will wish to engage civil enforcement agencies that are more likely to be successful in carrying out enforcement activity against the debtor. As a result, there is a danger that civil enforcement agencies and the bailiffs employed by them will fail to observe the required standards of conduct.

There are two control mechanisms that have the potential to constrain improper behaviour on the part of civil enforcement agencies. The first constraint arises out of the civil liability for wrongful seizure. The $C E A$ introduces several changes in the law which tend to increase the potential risk. Many of the rules which made it more difficult to sue the sheriff have been discarded. ${ }^{120} \mathrm{In}$ addition, the $C E A$ gives the debtor the right to recover deemed damages of $\$ 200$ whenever a failure to comply with the $A c t$ has caused the debtor to suffer a loss. ${ }^{21}$ These changes are modest in effect and unlikely in themselves to produce a significant constraint on behaviour, as they require the debtor to initiate legal action.

The more powerful control mechanism is the regulatory powers conferred on the sheriff under the $C E A$. There has been a fundamental restructuring of the role and function of the sheriff under the $C E A$. The sheriff is given extensive powers to screen applicants, monitor the performance of civil enforcement agencies and bailiffs and to 
suspend their operations where they act improperly. ${ }^{122}$ The $C E A$ gives the sheriff wide investigative powers and the power to issue written directions requiring a person to comply with the $A c t$ or to adopt or refrain from carrying out certain practices or procedures. ${ }^{123}$ The sheriff has a considerable latitude in judging the appropriateness of enforcement practices, since the Civil Enforcement Regulations provide a Code of Conduct for civil enforcement agencies and bailiffs which requires agencies and bailiffs to discharge their responsibilities with integrity and to "treat all persons fairly, courteously and with respect." ${ }^{124}$ The sheriff has the power to suspend the licence of a bailiff and the agreements negotiated between the government and the agencies contain provisions permitting the government to terminate the agreement on a variety of grounds. The sheriff unquestionably has sufficient power to monitor and ensure compliance with the $C E A$. The real question which remains to be answered is whether the sheriff will be given sufficient resources to be able to exercise those powers effectively.

Privatization may well result in an increase in the cost of enforcement activity borne by enforcing creditors. Under the prior system, the enforcing creditor did not pay for the total costs of enforcement. In effect, there was a public subsidization of enforcement activity. Under the new system, the enforcement costs are internalized and borne by the instructing creditor. This increase in cost may, however, be offset by an increased responsiveness on the part of civil enforcement agencies which may produce higher recoveries. If the increased costs of the privatized system are not matched by a corresponding increase in the amount recovered, creditors will be more likely to pursue enforcement strategies that do not involve a seizure of personal property. One would therefore anticipate a greater inclination on the part of creditors to pursue other remedies such as garnishment or to seek workouts, compromises or other voluntary arrangements with the debtor.

\section{SALE OR OTHER DISPOSITION}

There are a number of fundamental policy issues that must be addressed in formulating appropriate enforcement rules governing the sale of seized goods. The enforcement system must specify which methods of sales are permissible, identify which persons are empowered to conduct the sale and indicate the rights obtained by the purchaser at the sale. The enforcement rules must also identify who is to receive notice and what information must be given. Finally, the enforcement rules should describe the conditions under which a sale of the property to the creditor or a foreclosure of a security interest is permitted.

Civil Enforcement Regulation, supra note 52, ss. 21-33. In addition, the civil enforcement services agreements contracted between the Crown and civil enforcement agency contains contractual provisions giving the sheriff the power to conduct an audit or investigation, selting out detailed standards governing seizure, sale and distribution and giving the sheriff the right to suspend or terminate the agreement in the event of a default by a civil enforcement agency.

124 Civil Enforcement Regulation, supra note 52, s. 12, sch. 1, 2. 


\section{A. CONDUCT OF THE SALE}

The Seizures Act contained a strong preference in favour of public sales of seized goods. The general rule was that unless a court ordered otherwise, every sale should be by public auction or tender. ${ }^{25}$ Both the PPSA and the CEA move away from this traditional reliance on public auctions of seized property. The common concern was that restrictions on the available methods of sale produce sub-optimal recoveries and therefore operate to the detriment of both creditors and debtors. ${ }^{126}$ The statutes therefore abandon the notion of the public sale as the dominant or preferred method of disposing of the property. Instead, the creditor is given the power to sell the property by any commercially reasonable method, which may include a public auction, sale by tender or a public sale. ${ }^{127}$ The sale may be delayed if it commercially reasonable to do so. ${ }^{128}$

The primary difference between the two statutes concerns the party responsible for the conduct of the sale. Only a civil enforcement agency may conduct a sale pursuant to writ proceedings. ${ }^{129}$ Under the PPSA, it is the secured party who is responsible for the conduct of the sale. This difference in treatment can be justified on the basis of the difference in the relative expertise of the different classes of creditors. Enforcement creditors tend not to be repeat players. Their claims are often for small amounts, and they will usually have little experience in enforcement. ${ }^{130}$ In addition, a distribution of the proceeds of sale is subject to a pro rata system of sharing which requires a significant degree of expertise on the part of the person making the distribution. ${ }^{131}$ Secured parties, on the other hand, are far more likely to have the necessary experience in the disposition of seized collateral, and the question of distribution is far simpler since the issue will arise only in the event that there remains a surplus. ${ }^{132}$

\section{B. NOTICE REQUIREMENTS}

Both the CEA and the PPSA adopt a notice procedure under which a notice must be given prior to the intended sale. ${ }^{133}$ Under both statutes, the notice may be dispensed with if the goods are perishable or rapidly declining in value. ${ }^{134}$ However, the notice

Seizures $A c t$, s. 14(1). A private sale was permitted in two situations. A sheriff was permitted to sell by private contract if a public sale had failed to produce an adequate price. See Seizures $A c t$, s. 33. In addition, a secured party could exercise a power of sale provided in a security agreement. See Seizures Act, s. 30(1)(b). If this option were chosen, the secured party had to file a statutory declaration with the sheriff giving the details of the sale including the amount realized.

126. Enforcement of Money Judgments, supra note 35 at 105-6.

${ }^{127} C E A$, s. 48(d); PPSA, s. 60(2).

${ }^{128} \quad C E A$, s. $48(\mathrm{c}) ; P P S A$, s. $60(3)$.

129 CEA, s. $9(1)(\mathrm{c})$.

130 See supra note 113.

i.1 CEA, ss. 94-103.

112 PPSA, s. 61(1).

in CEA, s. 48(c); PPSA, s. 60(4)-(10).

134 CEA, s. 48(h),(h.1); PPSA, s. 60(15). The PPSA provision is somewhat wider in that it permits a sale without notice where the cost of storage is disproportionately large relative to its value, whereas the $C E A$ has no comparable provision. 
procedure provided in the PPSA is more stringent than that provided in the $C E A$. Under the PPSA, the notice must inform the debtor of the right to redeem the security interest or reinstate the security agreement and must provide details concerning the method of sale. The notice must be served at least twenty days prior to the proposed sale, and must be given to subordinate secured parties and other persons who have an interest in the property who have notified the secured party. A more modest notice procedure is set out in the $C E A$. The notice merely specifies the method of sale. The notice period is fifteen days, and the notice is given only to the debtor and the instructing creditor.

To a certain degree, this difference in treatment can be justified. The PPSA notice serves a wider purpose. It gives the debtor the information needed to exercise the right to redeem the collateral or reinstate the security agreement, ${ }^{135}$ and provides subordinate secured parties the opportunity to pay out the secured party and take over the conduct of the enforcement proceedings. It also provides the debtor or other interested party with information concerning the time and location of a public sale which gives that party an opportunity to monitor the sale, to make a bid for the goods or to object to the timing or method of sale.

The CEA notice serves a more limited purpose. The notice does not set out the amount required to satisfy the writ since this information has already been provided in the seizure documents, and there is no counterpart in the CEA to the right to reinstatement. This might explain the shorter time period associated with the notice. However, it is more difficult to understand why the notice is not required to be served on subordinate third parties, and why the legislation does not require the civil enforcement agency to disclose the date, time and location of a public auction.

\section{THE DUTY TO OBTAIN AN ADEQUATE PRICE}

At common law, a sheriff was required to sell the goods for a reasonable price. ${ }^{136}$ In doing so, the sheriff had to exercise "the judgment and discretion which a reasonably careful business man would exercise under the circumstances." ${ }^{137}$ If the sheriff failed to obtain any reasonable bids, the execution creditor could apply to court for a writ of venditioni exponas, which directed the sheriff to sell the goods for whatever price was obtainable. ${ }^{138}$ A secured party was also required to obtain a reasonable price when disposing of the collateral following a default. Earlier authority suggested that it was enough that the secured party act in good faith. ${ }^{139}$ However, this "pure heart, empty

135 PPSA, s. 62.

136 Pease v. Tudge (1915), 7 W.W.R. 804 (Sask. S.C.).

137 T.J. Fair \& Co. v. Wardstrom (1919), 47 D.L.R. 16 (Alta. S.C.A.D.) at 18.

13. Dunlop, supra note 59 at 314-15. Section 33 of the Seizures Act provided an altemative mechanism under which a sheriff could without a writ of venditioni exponas sell goods that remained unsold by private contract if the price is fair and reasonable having regard to all the circumstances.

139 Kennedy v. De Trafford, [1897] A.C. 180 (H.L.); J. \& W. Investments v. Black (1963), 41 W.W.R. 577 (B.C.C.A.); British Columbia Land \& Investment Agency v. Ishitaka (1911), 45 S.C.R. 302. 
head" standard has been replaced with the modern requirement that the secured party make reasonable efforts to obtain a proper price. ${ }^{140}$

Clearly, the common law duty of care owed by a sheriff was not unlike that owed by a secured party. ${ }^{141}$ Under the reformed law, they have been completely assimilated. Both the PPSA and the CEA adopt the standard of commercial reasonableness, and do not permit a waiver of this obligation. ${ }^{142}$ Under both statutes, a similar procedure is available in the event that a party wishes to obtain directions from the Court concerning the exercise of the enforcement remedies. ${ }^{143}$ This procedure is far more flexible than the old process for obtaining a writ of venditioni exponas, which almost certainly has been rendered a dead letter.

\section{SELF-DEALING}

Under certain conditions, both the creditor and the debtor have a common interest in obtaining the highest available price for goods that are sold under enforcement proceedings. Creditors who fail to do so face delay and the risk of non-recovery associated with the further enforcement proceedings that will need to be undertaken. The debtor is also interested in obtaining the highest available price in order to preserve the debtor's other property from enforcement measures. When these conditions pertain, restrictions on the method of sale are undesirable because they tend to limit the ability of the creditor to maximize recovery for the mutual benefit of the debtor and creditor. $^{144}$

In some situations this alignment of interests is not present, and the creditor does not have an incentive to maximize recovery on a sale of the property. ${ }^{145}$ If the value of the property is more than sufficient to satisfy the debt, a creditor will have no incentive to take efforts to maximize the surplus after payment of the creditor's claim. Any effort to do so will accrue solely to the debtor or a subordinate interest holder. An incentive to maximize recovery will not exist if the creditor is able to buy the goods at the enforcement sale. In this case, the secured creditor has a strong incentive to buy the goods at as low a price as possible. A similar problem exists where a secured party proposes to foreclose on its security interest where the value of the collateral exceeds the secured obligation. There is also the possibility that a creditor may offer the goods at a low price to a buyer with whom the creditor has an on-going business relationship.

Cuckmere Brick Co. Ltd. v. Mutual Finance Ltd., [1971] Ch. 949 (C.A.); Copp v. Medi-Dent Service (1991), 3 O.R. (3d) 570 (Gen. Div.) at 577.

Some jurisdictions have gone so far as to apply the same test. In Owen v. Daly, [1955] V.L.R. 442 the Victoria Supreme Court equated the duty of the sheriff with the duty of a mortgagee exercising a power of sale under the mortgage.

CEA, s. 2(g), (h); PPSA, ss. 66(1), 56(2). Section 56(2) of the PPSA is more restrictive in that it provides that the obligation cannot be varied, whereas $s$. $2(\mathrm{~h})$ invalidates the waiver only if it is given before the obligation arose.

CEA, s. 5; PPSA, s. 64.

A. Schwartz, "The Enforceability of Security Interests in Consumer Goods" (1983) 26 J.L. \& Econ. 117.

L. Zubrow, "Rethinking Article 9 Remedies: Economic and Fiduciary Perspectives" (1994) 42

U.C.L.A. L. Rev. 445 at $491-96$. 
For example, a bank may offer the automobiles it seizes under secured consumer loans to an automobile dealer that is financed by the bank. The price reduction on the automobiles substitutes for some other reduction in the cost of other services provided to the dealer. The bank will not have to absorb the full cost of the reduction if it can recover some or all of it out of a deficiency claim against the debtor. ${ }^{146}$

An optimal set of enforcement rules would give a creditor the greatest possible latitude to control the method and timing of the sale in circumstances where the creditor has an incentive to maximize recovery. However, this latitude is desirable only if there are sufficient safeguards to prevent creditor misbehaviour. The enforcement rules should therefore contain structural features that are designed to inhibit a creditor from pursuing non-maximizing behaviour. These measures should therefore seek to protect surpluses and prevent self-dealing or collusive sales.

Both the PPSA and the CEA give the debtor or a third party the right to damages for loss caused by a failure to realize on the goods in a commercially reasonable manner. ${ }^{147}$ However, this approach alone is subject to several serious limitations. It is a realistic possibility only if the lost surplus is sufficiently large in comparison to the cost of litigation. It is also difficult to prove unless the creditor has engaged in grossly deficient efforts. Furthermore, a debtor who is in financial distress is often not in a position to litigate.

The PPSA provides a number of features which tend to alleviate this problem. First, the secured creditor is required to give notice of the intended sale to any other person who has an interest in the property. ${ }^{148} \mathrm{~A}$ third party therefore has the opportunity to investigate and attempt to co-operate with the secured creditor in getting the best price for the property. If co-operation is not possible, the third party has the right to redeem the collateral by paying out the secured party. ${ }^{149}$ This course of action is far less useful to a debtor. However, the PPSA gives a debtor the right to reinstate a security agreement by paying the sums actually in arrears exclusive of the operation of an acceleration clause. ${ }^{150}$ This makes it easier for a debtor to take steps to protect property that is likely to yield a surplus.

Canadian courts have shown a willingness to introduce the equitable doctrine of marshalling within the context of the PPSA. ${ }^{151}$ The doctrine applies where there are two creditors of the same debtor; a senior creditor who has the right to resort to two funds of the debtor for payment of a debt, and a junior creditor who has a right to

See W. Whitford, "The Appropriate Role of Security Interests in Consumer Transactions" (1986) 7 Cardozo L. Rev. 959 at $994-5$.

(4) CEA, ss. 2(g), 4; PPSA, ss. 66(1), 67(1).

148 PPSA, s. 60(4).

149 Ibid., S. 63(1)(a).

iso Ibid., s. 63(1)(b).

151 National Bank of Canada v. Makin Metals Ltd., [1994] 4 W.W.R. 707 (Sask. C.A.); Steinbach Credit Union Lid. v. Manitoba Agricultural Credit Corp., [1992] 1 W.W.R. 448 (Man. Q.B.). 
resort to only one of the funds. ${ }^{152}$ In such a case, the court may marshal the funds so that the senior creditor must first resort to the fund in which the junior creditor has no interest. This will tend to reduce the potential for self-dealing by improving the alignment of interest between the creditors and debtor. In the absence of the doctrine, the oversecured senior creditor has little incentive to maximize the size of the surplus, since the benefits will accrue to the junior creditor. ${ }^{153}$

The manner in which the $P P S A$ deals with self-dealing and collusive sales is more problematic. Prior to the $P P S A$, a secured creditor was not allowed to bid at a public auction unless a court had given the secured creditor leave to do so. ${ }^{154}$ This preserved the common law position that a creditor could not bid at the sale except in the case of a judicially supervised sale. ${ }^{155}$ The PPSA relaxes this requirement. A secured party is permitted to buy the goods at a public sale if the price bears a reasonable relationship to the market price of the goods. ${ }^{156}$ The fairness of the price will be reviewed by a court only if the debtor or a third party commences litigation to review the sale to the creditor, and will give rise to a remedy only if the debtor or third party can prove that the secured creditor failed to act in a commercially reasonable manner and that this failure caused a loss to the plaintiff. ${ }^{157}$

The secured creditor controls the timing and advertising of the sale. If a secured party is permitted to buy the goods at a public sale, the secured party may adjust the method, timing and advertising of the sale to minimize the potential for competitive bids from third parties. By way of illustration, suppose that a secured creditor who finances the acquisition of farm implements by farmers finds that an economic downturn has resulted in an increase in its inventory of repossessed equipment. If the secured creditor is prohibited from buying the equipment, it will attempt to maximize recovery on a sale. In doing so it may decide not to put the machinery on the market until conditions improve. However, if the secured creditor is able to bid at a public sale, the secured creditor may dump all the seized equipment on the market under unfavourable conditions. The secured party then buys the equipment at the public sale with the intention of selling it privately when conditions improve.

Courts have expressed concern that permitting bidding by a creditor may endanger the integrity of the public sale mechanism. ${ }^{158}$ It may be more difficult to attract potential buyers to public sales if they know that they must compete with a secured

P.V. Baker \& P.St.J. Langan, Snell's Principles of Equity (28th ed., 1982), at 415-7. See also First Invesiors Corp. v. Veeradon Developments LId. (1985), 65 A.R. 135, var'd (1986) 71 A.R. 82, rev'd (1988) 84 A.R. 364 (C.A.).

15.

L. Zubrow, supra note 145 at 544-46.

Seizures Act, s. 29(6). See Gray-Campbell Co. v. Morrison, [1924] 2 W.W.R. 112 (Alta. S.C.A.D); Stewart v. Cocciolone, [1930] 3 W.W.R. 141 (Alta. S.C.T.D.).

Canadian Permanent Trust Co. v. King Art Developments Lid. (1984), 32 Alta. L.R. (2d) I (C.A.); Gordon Grant \& Co. v. Bloos, [1926] A.C. 781 (P.C.).

PPSA, s. 60(11).

Ibid., ss. 66(1), 67(1).

See Canadian Permanent Trust Co. v. King Art Developments Lid., supra note 155 at 15 . See also R. Washburn, "The Judicial and Legislative Response to Price Inadequacy in Mortgage Foreclosure Sales" (1980) 53 So. Cal. L.R. 843 at 849. 
party. The secured party has superior information about the property being sold which will permit it to out-manoeuvre a third party in a bidding contest. Although bidding by the secured party can prevent property from being sold at a throwaway price, this could also be accomplished by setting an upset price. The question whether a mortgagee should be entitled to purchase the property and sue for the deficiency was a controversial issue under Alberta land mortgage law. It was ultimately decided that a mortgagee should be permitted to do so. However, a crucial factor in permitting this practice was that there were sufficient procedural safeguards against abuse. The court determines the method and timing of the sale and may review the fairness of a bid. ${ }^{159}$ At minimum, the PPSA should provide a similar rule.

The problem of a collusive sale to a third party is more difficult to regulate or detect. A sale to a buyer who has an on-going business relationship with the creditor does not necessarily indicate that the transaction is collusive. The sale to such a customer may produce higher prices because the secured party can reduce its costs in searching for potential buyers. It is doubtful whether a statutory rule could be devised to adequately address this problem. Therefore, close judicial scrutiny of private sales to related or associated parties may be the only feasible response.

The $C E A$ adopts a somewhat different approach in regulating potentially self-dealing transactions. The statute does not indicate whether an enforcement creditor may bid at a public sale. At common law, a sale by the sheriff to an execution creditor was permitted without any need for a court order. ${ }^{160}$ However, the sheriff's office has been privatized, and the resolution of the issue may hinge on whether a civil enforcement agency is to be treated as the creditor's agent so as to attract the rule that a creditor cannot bid at the sale where the sheriff is acting as agent of the creditor rather than as a public officer. ${ }^{161}$ This may ultimately depend upon the degree of control and independence of action exercised by the civil enforcement agency. If a civil enforcement agency fails to exercise any control or discretion over the method of sale and merely carries out the instructions of the instructing creditor, there is obviously a greater need to provide protection against self-dealing transactions. It might be argued that there is less danger of self-dealing in relation to writ proceedings, since the sheriff's power to investigate complaints provides an additional control over abusive practices. This argument is unconvincing. A review of self-dealing transactions requires an assessment of the value of goods and the available markets for them, therefore making them more difficult to detect than abusive seizure tactics.

The $C E A$ also provides a mechanism through which a civil enforcement agency may sell the property to an enforcement creditor by private sale. ${ }^{162}$ The agency must give notice of the terms of the sale to the enforcement debtor and to other enforcement

See Mortgage Remedies in Alberta, supra note 19 at 211-230.

Dunlop, supra note 59 at 316.

See McCormick v. Haworth (1929), I W.W.R. 129 (Sask. C.A.). The court held that the common law rule that a mortgagee is not permitted to bid at the mortgage sale is not altered by a statutory requirement that a sheriff undertake the sale, since the sheriff does not act in the capacity of a public officer but only as an agent of the mortgagee.

$C E A$, s. 48(f), (g). 
creditors who have related writs. If the debtor or other enforcement creditor objects within a fifteen day period, a court order is needed to validate the sale. This procedure is similar to the foreclosure procedure set out in the $P P S A .^{163}$ However, it differs in that the notice is sent to a more limited class of registered parties. The PPSA notice must be given to all persons who have registered a financing statement against the name of the debtor or who have notified the secured party of their interest. It is difficult to see why the $C E A$ notice is limited to other registered enforcement creditors, since subordinate third parties will also be affected by the sale.

\section{E. RIGHTS OF PURCHASERS}

Both the CEA and the PPSA provide that a purchaser at an enforcement sale obtains the debtor's interest in the goods free from any subordinate interests. ${ }^{164}$ The PPSA provision provides that the purchaser must be acting in good faith. It also provides that a secured party's failure to comply with the procedural requirements of the section does not invalidate the sale. Although the $C E A$ does not contain this additional language, a purchaser who acts in bad faith is unlikely to attract any sympathy from the courts. There may be a greater latitude under the $C E A$ to set aside sales where there has been a failure by a civil enforcement agency to discharge its duties. The courts would set aside sales where the defect went to the creditor's substantive right to conduct enforcement proceedings. ${ }^{165}$ This might occur where the writ was invalid. ${ }^{166}$ However, it also had the discretion to set aside a sale where the defect was more in the nature of a procedural irregularity, although the tendency was to confirm the sale in such cases. ${ }^{167}$

At common law, a sheriff did not impliedly give a purchaser any warranty as to title. ${ }^{168} \mathrm{~A}$ sheriff was liable to a purchaser only if the sheriff knew of the defect, but failed to disclose it to the purchaser. ${ }^{169}$ The CEA does not indicate whether or not a civil enforcement agency is to be excepted from the usual implied terms as to title. A similar protection did not extend to a secured party who disposed of collateral upon default, and there are no compelling reasons for treating a civil enforcement agency differently. Under the $C E A$, a purchaser may have greater difficulties determining if the goods are being sold pursuant to writ proceedings or pursuant to other distress proceedings. The onus should therefore be upon the civil enforcement agency to expressly contract out of implied terms as to title if that is its intention. ${ }^{170}$

PPSA, s. 62.

CEA, ss. 48(i), 34(2); PPSA, s. 60(12).

Dunlop, supra note 59 at 318-20.

Overn v. Strand, supra note 90.

Turiff \& Edinger, supra note 58 at 166.

Taugen (Tangen) v. Vanderburgh (Vanderberg) (1908), 9 W.L.R. 269 (Alta. S.C.T.D.).

Ibid.

The Alberta Queen's Printer has produced a bill of sale for use by civil enforcement agencies which expressly excludes any warranty as to title. This document has no official status as it is not a document that is prescribed by the $C E A$ or regulations. 


\section{RESTRICTIONS ON ENFORCEMENT}

The present approach to regulation is made up of three components: anti-deficiency protection, a restriction on after-acquired property clauses and exemptions. In order to assess these provisions, we must try to understand what the legislators hoped to achieve. It is here that we run into difficulties. The policy objectives underlying the restrictions are often unclear or ambiguous. Furthermore, the policy reasons themselves appear to have changed over time. As a result, the restrictions on enforcement represent the least satisfactory aspect of the current enforcement systems.

\section{A. ANTI-DEFICIENCY RESTRICTIONS}

Anti-deficiency legislation was originally intended to limit the amount of farm debt arising out of the acquisition of farm equipment. ${ }^{171}$ It was introduced in the aftermath of the Great Depression as a part of a larger effort to gain control over the regulation of the credit-granting practices of banks and other (eastern) financial institutions. Alberta farmers exercised their influence within the province, while the banks made their appeals to Ottawa. The constitutional struggle over debt adjustment legislation was the inevitable consequence. Most of the provincial legislation did not survive. The antideficiency legislation was not challenged and therefore persisted for a time as an isolated reminder of a largely forgotten era.

Upon the coming into force of the PPSA, the legislation was modified so that it only applied to consumers. There are several possible justifications for anti-deficiency legislation in the consumer context. The first is that it is essentially a paternalistic concern with the overconsumption of credit. The provision will have the effect of reducing the availability of credit because secured credit sales financers will respond by increasing down-payments and shortening the maturity of the credit. A second possible justification is that anti-deficiency legislation provides debtors with an insurance feature that protects the debtor from the effects of loss of employment and other external reasons for default. ${ }^{172}$ Another possibility is that the legislation reduces the potential for in terrorem enforcement which coerce payment even though the debtor may have a valid defence. A debtor is more likely to have a defence where the financing takes the form of credit extended by a seller as opposed to lender-based financing. These defences would usually arise from the provision of defective goods or services. The threat to enforce the security interest becomes less credible if the right to pursue a deficiency is thereby lost.

Whether the primary objective of the provision is to reduce the supply of consumer credit or to provide an insurance feature in secured consumer credit agreements which the debtor desires but which the market does not provide, it would seem that the

171 See notes 19 to 22 and accompanying text.

172 M.H. Schill, "An Economic Analysis of Mortgagor Protection Laws" (1991) 77 Va. L. Rev. 489 at 492-500. The insurance rationale has been used to justify anti-deficiency legislation in relation to land in resource based jurisdictions where the effects of economic downturns are particularly sharp. 
approach is incomplete. It does not apply to lenders who take purchase money security interest in the collateral. This creates a distortion in the consumer credit market by favouring lender based financing. ${ }^{173}$ If the real concern is over in terrorem enforcement tactics, the limitation of the provision to secured sales credit might be justified. However, it is debatable whether this problem is sufficiently widespread so as to justify such an overbroad legislative response.

\section{B. ADD-ON AND BLANKET SECURITY RESTRICTIONS}

Section 13(2) of the PPSA limits the effectiveness of after-acquired property clauses in consumer goods and in growing crops. The provision is drawn from the Uniform Commercial Code. ${ }^{174}$ Grant Gilmore indicates that at one stage the drafters of the Uniform Commercial Code intended to include a "full-scale treatment of the problems of consumer finance."175 This plan was later abandoned when it became clear that no consensus could be achieved, and most of the consumer protection provisions were removed. However, the add-on restriction survived as one of "a few curious traces" of the original plan. ${ }^{176}$

Section 13(2)(b) provides that a security interest does not attach to after-acquired consumer goods, other than an accession, unless it is a purchase-money security interest or a security interest in collateral acquired by the debtor as replacement for collateral described in the security agreement. The provision is intended to control the use of "add-on" clauses in security agreements. It discourages the use of blanket security clauses which encumber all of the debtor's present and future goods. Instead, the consumer financer must take security on specific items in existence at the time the security agreement is executed.

The restriction functions somewhat like an exemption in that it insulates certain kinds of property (future property) from the enforcement remedies of secured creditors. However, if its purpose is to provide a kind of exemption, it does so in a crude manner. It does not restrict enforcement against property needed to earn a livelihood. Nor is it effective to prevent sales of low value collateral. The secured creditor can enforce a security interest in all household goods that were in existence at the time the security was executed and also any replacement goods. Indeed, the provision may even compound the lost value problem since only the older consumer goods (which are not likely to be worth as much as the newer consumer goods) will be available for seizure and sale. A second problem with this form of regulation is that it is potentially misleading. The use of blanket security or add-on clauses is not prohibited. The clauses

The Saskatchewan Law Reform Commission recommended that a "seize or sue" election be imposed on all purchase-money security interests. It therefore would cover both lender and vendor based financing. See Law Reform Commission of Saskatchewan, Proposals for Reform of Consumer Credit Law (Saskatoon: Law Reform Commission of Saskatchewan, 1989) at 30-35. UCC $\$ 9-204(4)$.

175 G. Gilmore, Security Interests in Personal Property, vol. 1 (Boston: Little Brown \& Co., 1965), at 357.

176 Ibid. at 293. 
are merely rendered ineffective. A consumer who reads the security agreement will therefore be misinformed about his or her rights.

\section{EXEMPTIONS}

The Alberta Law Reform Institute describes the underlying purpose of exemptions legislation:

The enforcement processes should not destroy the debtor as a viable economic and social entity. The law, in the interests of all participants, must protect debtors from forfeiting so much of their property and potential as would render it impossible or unreasonably difficult for them to maintain themselves and their dependents at a reasonable standard and with reasonable security that they can continue to do so. There is also a considerable social interest in preserving the viability of debtors. If creditors were allowed to destroy debtor's economic viability, their continued maintenance would fall to society. The result would be a net asset transfer from the public purse to creditors. ${ }^{177}$

This explanation contains both paternalistic and communitarian elements to it. It is paternalistic in that it seeks to protect debtors from the consequences of their actions by preventing them from entering into contracts which may impair their ability to gain a livelihood. It is communitarian in that it seeks to limit the creditor's right to enforce the bargain with the debtor if enforcement results in undesirable social consequences to the community. The exemption provisions may also go some ways towards ameliorating the "lost value" problem which occurs when the value of the property to the debtor substantially exceeds its realization value. ${ }^{178}$ The $C E A$ exempts "household furnishings and appliances" that are of a value not exceeding $\$ 4000$. The debtor is also given the right of selection. This would allow the debtor an exemption in relation to those articles in which there is the greatest disparity between the debtor's valuation and market value.

Between 1935 and 1984, exemptions could be claimed against a secured creditor in Alberta. In 1984, the exemptions legislation was changed. The legislation no longer gave a debtor the right to claim an exemption against a secured creditor. The $C E A$ provides that a waiver of an exemption by a debtor is void. However, a creditor can indirectly contract out of the exemptions by taking a security interest in the debtor's property. The key issue is whether there are any reasons why the exemptions should not be available against secured creditors.

It may be argued that the case for exemptions is weaker where secured credit is involved. The execution of a security agreement that describes the collateral may be seen as a method of informing debtors that vital property is at risk in the event of default. However, exemptions policy is not based upon a concern about insufficient information. It is founded upon a concern over the debtor's economic integrity and a concern that private enforcement will produce undesirable third party effects, the costs 
of which are not borne by the parties to the contract. These justifications apply to both secured and unsecured creditors.

\section{A RATIONALIZED APPROACH}

The justification that has been advanced in favour of exempting certain types of property from judgment enforcement proceedings applies equally to enforcement by secured creditors. It follows from this that secured creditors who take security interests in consumer goods should be subject to a similar set of exemptions. This would not represent a surprising innovation in Alberta. Prior to 1984, the exemptions extended to seizures under chattel mortgages. An exception should be made where a purchasemoney security interest is taken in the exempt property, since the extension of credit permitted the acquisition of the goods by the debtor in the first instance. This approach was adopted in New Brunswick ${ }^{179}$ and first proposed in Saskatchewan. ${ }^{180}$ The present restriction against blanket security clauses should be repealed, since it appears to provide a less effective response to the same problem.

It is also necessary to re-evaluate the role of anti-deficiency legislation. If its purpose is to restrict the consumption of credit or to provide consumers with an insurance feature, its scope should be widened to cover purchase-money security interests granted by lenders. ${ }^{181}$ Although the problem of unjustified threats to repossess despite consumer defences is greater in connection with secured sales financing, the use of antideficiency legislation to redress is simply too crude of a response.

This proposal attempts to create a more coherent approach to regulation. It is important to understand the limitations inherent in this approach. It attempts to work out a consistent approach to regulation which does not draw artificial distinctions between secured and unsecured credit. However, the underlying justifications for regulation remain controversial. ${ }^{182}$ There is debate over whether the lost value problem is sufficiently significant to warrant interference with a contractual bargain. ${ }^{183}$ Even if it is accepted that the lost value problem is present, there is further controversy over whether the threat to destroy value is a legitimate collection tactic. $^{184}$

Personal Property Security Act, S.N.B. 1993, c. P-7.1, s. 58(3)-(7). See also C. Walsh, An Introduction to the New Brunswick Personal Property Security Act (Fredericton: New Brunswick Geographic Information Corporation, 1995) at 268-70.

Law Reform Commission of Saskatchewan, Proposals for a New Personal Property Security Act (Saskatoon: Law Reform Commission of Saskatcliewan, 1992) at 81-82.

See supra note 173 at $30-35$.

R.E. Scott, "Rethinking the Regulation of Coercive Creditor Remedies" (1989) 8 Col. L. Rev. 730 at 765-86; J. Braucher, "Defining Unfairness: Empathy and Economic analysis at the Federal Trade Commission" (1988) 68 Bost. U.L. Rev. 349.

A. Schwartz, "The Enforceability of Security Interests in Consumer Goods" (1983) 26 J.L. \& Econ. 117; Whitford, supra note 146; D. Cohen \& K.L. Knetsch, "Judicial Choice and Disparities Between Measures of Economic Values" (1992) 30 Osgoode Hall L.J. 737 at 768-69.

R.E. Scott, "Rethinking the Regulation of Coercive Creditor Remedies" (1989) 89 Col. L. Rev. 730 at 734-56; Whitford, ibid. at 986-92. 


\section{JUDICIAL INTERVENTION}

In most jurisdictions, the onus is on a debtor to initiate legal proceedings to challenge the legal validity of enforcement proceedings. In Alberta, this onus was reversed through the unique notice of objection procedure. This procedure originally applied to both writ proceedings and enforcement proceedings by secured creditors. Under the reformed system, it is available only in relation to writ proceedings. In order to determine whether this difference in treatment is justified, it is useful to examine the grounds for objection that may be raised by a debtor and to consider the costs and benefits of the procedure in this light.

\section{A. GROUNDS FOR OBJECTION}

There are two different types of objections that can be raised in connection with enforcement proceedings. A legal objection challenges the validity of the seizure with the result that the enforcement proceedings are declared unlawful and the goods are returned to the debtor. An objection on equitable grounds does not challenge the legal validity of the seizure, but instead asks the court to grant discretionary relief to the debtor on equitable grounds.

A number of different legal objections may be employed by a debtor to challenge a seizure under writ proceedings. The debtor might claim that the manner of seizure was unlawful, the pre-conditions for a valid seizure had not been satisfied, the goods were exempt or the seizure was excessive. In the case of enforcement proceedings under security agreements, the legal grounds for objection are somewhat different. The debtor may claim that the seizure is illegal because there has not been an event of default. A similar claim is less likely to be made under writ proceedings since an unsecured creditor must obtain judgment and the debtor will therefore have had an opportunity to contest the validity of the claim. Although a secured creditor is not subject to provincial exemptions, there are several different restrictions that apply where consumer goods are involved. A debtor may also object to the manner in which it was conducted or on the ground that the seizure was excessive.

The power to grant equitable relief to debtors was long-standing in Alberta. Indeed, the original reason for judicializing the enforcement process was to give courts the opportunity to grant such equitable relief. Under the Seizures Act, a court was empowered to approve a proposal by the debtor to pay the debt in instalments. ${ }^{185}$ The court could also grant relief against in terrorem enforcement proceedings that are designed to cause detriment to the debtor without producing a sufficient legitimate benefit to the creditor. ${ }^{186}$

Section 5 of the CEA and s. 64 of the PPSA give the court the power to control enforcement proceedings, including the power to stay enforcement of rights. The question whether the broad equitable jurisdiction has been retained under the reformed 
law is not beyond controversy. The Saskatchewan Court of Appeal in Andrews v. Mack Financial (Canada) Ltd. ${ }^{187}$ took a restrictive view of the court's jurisdiction under the PPSA. The Court held that an equivalent provision of the Saskatchewan PPSA does not permit the court to rewrite the substance of the agreement. It was of the view that the section could be used to prevent a secured party from acting in a commercially unreasonable manner, but could not be used to pursue a policy of consumer protection or debtor relief. In Alberta, there is a compelling reason why the Andrews decision should not be followed. Section 18 of the Judicature $A c t,{ }^{188}$ which also traces its lineage back into the Great Depression, ${ }^{189}$ clearly gives the court the power to stay enforcement and to order repayment in instalments. ${ }^{190}$ It is therefore unnecessary to derive this power from the PPSA or the CEA. The power to stay in terrorem enforcement proceedings should also be maintained, as it is consistent with the obligation to act in good faith and in a commercially reasonable manner. ${ }^{191}$

\section{B. THE NOTICE OF OBJECTION PROCEDURE}

One might begin by asking if a notice of objection procedure is a desirable feature. After all, most Canadian jurisdictions place the onus upon the debtor to initiate such proceedings. The implicit trade-offs are reasonably clear. Although the procedure will give a debtor an enhanced ability to control unlawful or opportunistic creditor behaviour, it may also be invoked where there are no proper grounds for objection. This will have the effect of making the seizure of goods more costly. Part of this cost will be borne by the suppliers of credit and part will be borne by the debtors who consume it. ${ }^{192}$ Creditors will respond $e x$ ante by restricting the availability of credit, and ex post by seeking substitutes for seizure such as voluntary workouts or settlements. ${ }^{193}$ There is very little in the way of empirical evidence which can be used to assess whether the benefits exceed the costs.

I have argued throughout that in designing the enforcement system, similar rules should be applied to secured and unsecured creditors unless there is some reason that justifies a difference in treatment. The same policy objectives exist in relation to proceedings to enforce security agreements. There is no reason to believe that either the legal objections to seizure or objections on equitable grounds are more prevalent in the

[1988] 2 W.W.R. 747 [hereinafter Andrews].

R.S.A. 1980 , c. J-1.

See notes 4-10 and accompanying text.

Royal Trust Corp. of Canada v. Kendel Adjusters Lid. (1984), 32 Alta. L.R. (2d) 383 (C.A.). Section 18 of the Judicature $A c t$ is not restricted to orders made following writ proceedings but applies as well to an order made following a distress for rent.

PPSA, s. 66(1); CEA, s. 2(g).

See W.C. Whitford \& H. Laufer, "The Impact of Denying Self-Help Repossession of Automobiles: A Case-Study of the Wisconsin Consumer Act" [1975] Wis. L. Rev. 607.

See C.W. Grau \& W.C. Whitford, "The Impact of Judicializing Repossession: The Wisconsin Consumer Act Revisited" [1978] Wis. L. Rev. 983. The state of Wisconsin instituted a requirement of judicialized repossession under which a secured creditor was required to obtain a prior court determination that the creditor was entitled to repossess the collateral before a repossession could occur. The study confirmed that this led to a greater reliance on workouts and less on repossession as a collection practice. 
case of unsecured credit. Indeed, there is more likely to be a dispute about the existence of an event of default or a justification for non-payment in the case of a secured creditor. ${ }^{194}$ Although exemptions cannot be claimed against secured creditors, there are several restrictions on the enforcement of security interests in consumer goods. There is also a greater prospect of the court exercising its power to grant equitable relief in the case of enforcement by a secured creditor. Courts are reluctant to exercise their power to grant relief when it has the effect of exposing the creditor to a significant risk of loss. A fully secured creditor will have no incentive to bargain with the debtor, and will typically seek an immediate sale of the property regardless of market conditions. $^{195}$ The power to reschedule payments can be seen as a method by which the court can protect against the destruction of surplus value caused by the forced sale of the collateral. ${ }^{196}$

In the absence of a notice of objection system, a debtor will usually need to retain a lawyer in order to pursue the objection. The option is therefore of least value in the consumer credit context where the value of the collateral is often low. But it is precisely here that a debtor is most likely to have a valid objection to the seizure or sale of the goods. This analysis suggests that the availability of the notice of objection procedure should not depend upon the secured or unsecured status of the creditor. Rather, the notice of objection procedure should be available in respect of a seizure of consumer goods under any form of enforcement proceeding.

\section{CONCLUSION}

The enactment of the PPSA and CEA has profoundly altered the structure and operation of the enforcement systems available to creditors. In this article, I have argued that a common set of principles should be adopted unless there is some reason to justify a difference in treatment. There are two implications that arise out of this approach. The first concerns the interpretation of the legislation by the judiciary. The legislative reforms makes it necessary to rethink many of the rules and principles that formerly governed. The courts must work out a new set of principles and approaches which will produce greater coordination and conceptual integration between the $C E A$ and PPSA enforcement systems. This will lead to the emergence of a shared set of principles governing the exercise of enforcement remedies by creditors on such matters as the power of seizure, the creditor's duty of care, liability for wrongful seizure and the exercise of the court's power to stay enforcement or grant other relief. The courts must also work through the implications of privatization in order to determine how much of the prior law governing the rights and obligations of the sheriff should be retained and how much should be discarded in favour of a pure agency analysis.

A justification for non-payment would most often occur in the case of vendor based financing of consumer goods since product defences can be raised against an assignee of the chattel paper. See Law of Property Act, R.S.A. 1980, c. L-8, s. 48, re-en. 1988, c. P-4.05, s. 87. By way of contrast, a maximizing undersecured creditor has an incentive to agree to reschedule payments so long as the expected payments are greater than the expected depreciation of the goods.

1x. See Paccar of Canada Ltd. v. Canadian Concrete Products Ltd. (1984), 42 Alta. L.R. (2d) 34 (Q.B.). The fact that the secured party is fully secured is an important factor in granting an order. 
The second implication is that further legislative amendments will be needed in order to complete the reform agenda. I have argued that the availability of the notice of objection procedure should not depend upon whether the enforcement proceedings are brought by a secured party or a judgment creditor, but should depend upon the nature of the goods that are seized. In a similar vein, I have argued that the restrictions on enforcement should be restructured by replacing the existing restrictions with a system of exemptions covering seizures under security agreements. The policy objectives underlying the anti-deficiency legislation must also be articulated so that the social desirability of the legislation may be reappraised. In short, it has come time to review the role of consumer protection measures in the newly reformed enforcement system. 